ARTICLE

\title{
Unveiling the key factor for the phase reconstruction and exsolved metallic particle distribution in perovskites
}

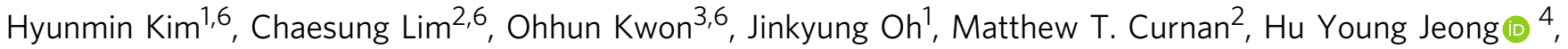
Sihyuk Choi ${ }^{5 凶}$, Jeong Woo Han (10 ${ }^{2 \otimes} \&$ Guntae Kim (10) ${ }^{1 凶}$

To significantly increase the amount of exsolved particles, the complete phase reconstruction from simple perovskite to Ruddlesden-Popper (R-P) perovskite is greatly desirable. However, a comprehensive understanding of key parameters affecting the phase reconstruction to R-P perovskite is still unexplored. Herein, we propose the Gibbs free energy for oxygen vacancy formation in $\operatorname{Pr}_{0.5}(\mathrm{Ba} / \mathrm{Sr})_{0.5} \mathrm{TO}_{3-\delta}(\mathrm{T}=\mathrm{Mn}, \mathrm{Fe}, \mathrm{Co}$, and $\mathrm{Ni})$ as the important factor in determining the type of phase reconstruction. Furthermore, using in-situ temperature \& environment-controlled $\mathrm{X}$-ray diffraction measurements, we report the phase diagram and optimum ' $x$ ' range required for the complete phase reconstruction to R-P perovskite in $\mathrm{Pr}_{0.5} \mathrm{Ba}_{0.5-x} \mathrm{Sr}_{x} \mathrm{FeO}_{3-\delta}$ system. Among the $\mathrm{Pr}_{0.5} \mathrm{Ba}_{0.5-x} \mathrm{Sr}_{x} \mathrm{FeO}_{3-\delta \prime}\left(\mathrm{Pr}_{0.5} \mathrm{Ba}_{0.2} \mathrm{Sr}_{0.3}\right)_{2} \mathrm{FeO}_{4+\delta}-\mathrm{Fe}$ metal demonstrates the smallest size of exsolved $\mathrm{Fe}$ metal particles when the phase reconstruction occurs under reducing condition. The exsolved nano-Fe metal particles exhibit high particle density and are well-distributed on the perovskite surface, showing great catalytic activity in fuel cell and syngas production.

\footnotetext{
${ }^{1}$ School of Energy and Chemical Engineering, Ulsan National Institute of Science and Technology (UNIST), Ulsan 44919, Republic of Korea. ${ }^{2}$ Department of Chemical Engineering, Pohang University of Science and Technology (POSTECH), Pohang 37673, Republic of Korea. ${ }^{3}$ Department of Chemical and Biomolecular Engineering, University of Pennsylvania, Philadelphia, PA 19104, USA. ${ }^{4}$ Department of Materials Science and Engineering and UNIST Central Research Facilities (UCRF), Ulsan National Institute of Science and Technology (UNIST), Ulsan 44919, Republic of Korea. ${ }^{5}$ Department of Mechanical Engineering (Aeronautics, Mechanical and Electronic Convergence Engineering), Kumoh National Institute of Technology, Gyeongbuk 39177, Republic of Korea. ${ }^{6}$ These authors contributed equally: Hyunmin Kim, Chaesung Lim and Ohhun Kwon. ${ }^{凶}$ email: sh.choi@kumoh.ac.kr; jwhan@postech.ac.kr; gtkim@unist.ac.kr
} 


\section{T} ailoring the functionality of perovskite oxides $\left(\mathrm{ABO}_{3}\right)$ by decorating the surface with catalytically active particles plays an important role in energy-related applications such as fuel cells, electrolysis cells, metal-air batteries, and supercapacitors ${ }^{1-6}$. The catalyst particles are typically prepared by deposition techniques (e.g. infiltration, chemical vapor deposition, and pulsed laser deposition), in which the catalysts are embedded onto the surface from external precursors ${ }^{7-9}$. However, these techniques require redundant heat-treatments for preparation and the catalyst particles suffer from agglomeration and/or coarsening over time, resulting in performance degradation ${ }^{10,11}$. In this respect, it is of great importance to develop more robust and time-efficient catalyst preparation method. Exsolution phenomenon on the basis of in-situ growth of metal particles has been suggested as an advanced approach to designing perovskite matrix with electro-catalytically active particles ${ }^{12,13}$. In this approach, catalytically-active metal elements (e.g. $\mathrm{Pd}, \mathrm{Ru}, \mathrm{Co}, \mathrm{Ni}$, and $\mathrm{Fe}$, etc...) are initially incorporated into the B-site of perovskite oxides, and then exsolved as metallic particles from the perovskite support under reducing atmosphere ${ }^{14,15}$. As compared with the conventional catalyst preparation methods, the in-situ exsolution process provides benefits of time-efficient catalyst preparation, enhanced catalyst lifetime, and robust thermal stability 16,17 . Notwithstanding the advantages, two major thresholds hinder the practical application of the exsolution process: (i) restricted diffusion of catalytically active cations to the surface due to preferential segregation within the bulk ${ }^{18}$, and (ii) structural destruction and/or insulating phase evolution after excessive cation defect formation ${ }^{19}$.

In order to address the challenges of the exsolution phenomenon, $\mathrm{A}$-site deficient perovskites $(\mathrm{A} / \mathrm{B}<1)$ has been extensively employed as an attractive methodology $y^{2,20-22}$. In A-site deficient perovskites, formation of oxygen vacancies is promoted by phase stabilization from non-stoichiometric perovskite to defect-free perovskite under reducing condition, facilitating the B-site exsolution $^{23,24}$. Hence, the $\mathrm{B}$-site exsolution level is proportional to A-site deficiency range ( $\alpha$ ' for $\mathrm{A}_{1-\alpha} \mathrm{BO}_{3-\delta}$ ). Meanwhile, there exists restriction in the variation of A-site deficiency range (about $0<\alpha<0.2$ for $\mathrm{A}_{1-\alpha} \mathrm{BO}_{3-\delta}$ ) because excessive A-site deficiency may be accompanied by formation of undesirable A-site oxide phases 19,25 . Given these aspects, an alternative corresponding method to further trigger the B-site exsolution is using the in-situ phase reconstruction from simple perovskite to Ruddlesden-Popper (R-P) perovskite oxides $\left(\mathrm{A}_{n+1} \mathrm{~B}_{\mathrm{n}} \mathrm{O}_{3 \mathrm{n}+1}\right.$ with $\mathrm{n}=1,2$, and 3 ) via reduction process ${ }^{26,27}$. This strategy facilitates abundant formation of oxygen vacancies during the phase reconstruction, breaking the bottleneck of exsolution capability.

$$
\mathrm{ABO}_{3} \underset{\text { After reduction }}{\longrightarrow} \frac{1}{2} \mathrm{~A}_{2} \mathrm{BO}_{4}+\frac{1}{2} \mathrm{~B}+\frac{1}{2} \mathrm{O}_{2}
$$

From Eq. 1, it is presumable that considerable number of cations at B-site will be reduced into metals without A-site segregation after phase reconstruction from simple perovskite $\left(\mathrm{ABO}_{3}\right)$ to $\mathrm{n}=1 \mathrm{R}-\mathrm{P}$ perovskite $\left(\mathrm{A}_{2} \mathrm{BO}_{4}\right)$. Although several perovskites have exhibited superior distribution of catalyst particles on the surface via phase transition to R-P perovskite ${ }^{28-30}$, the comprehensive understanding of key factors modulating the phase reconstruction to R-P perovskite is still an open question.

Inspired by the above perspectives, the goal of this study is to identify the significant factor contributing to the phase reconstruction from simple perovskite to R-P perovskite. Here, we systematically report the Gibbs free energy for oxygen vacancy formation $\left(\mathrm{G}_{v f-\mathrm{O}}\right)$ of perovskite oxides with various cations as the unprecedented factor affecting the phase reconstruction. The type of phase reconstruction could be predicted with the $\mathrm{G}_{v f-O}$ value from $\mathrm{PrO}$ and $\mathrm{TO}_{2}$ networks in $\mathrm{Pr}_{0.5}(\mathrm{Ba} / \mathrm{Sr})_{0.5} \mathrm{TO}_{3-\delta}(\mathrm{T}=\mathrm{Mn}$,
$\mathrm{Fe}, \mathrm{Co}$, and $\mathrm{Ni}$ ), in which the most appropriate cations for the complete reconstruction to R-P perovskite are determined. Afterwards, the phase diagram from in-situ temperature and environment-controlled X-ray diffraction (XRD) measurements reveals the phase reconstruction tendency of $\operatorname{Pr}_{0.5} \mathrm{Ba}_{0.5-x} \mathrm{Sr}_{x-}$ $\mathrm{FeO}_{3-\delta}(x=0,0.1,0.2,0.3,0.4$, and 0.5 , abbreviated as PBSF in Supplementary Table 1) materials with respect to ' $x$ ' value and reduction temperature. Furthermore, the as-exsolved Fe metal particle size and distribution for PBSF after reduction process are observed from microscopy analysis. In accordance with the theoretical calculations and experimental data, $\operatorname{Pr}_{0.5} \mathrm{Ba}_{0.2} \mathrm{Sr}_{0.3} \mathrm{FeO}_{3-\delta}$ (A-PBSF30) is adopted as the optimized electrode material for symmetrical solid oxide cell (S-SOC) and demonstrates exceptional electrochemical performance $\left(1.23 \mathrm{~W} \mathrm{~cm}^{-2}\right.$ at $800^{\circ} \mathrm{C}$ under fuel cell mode and $-1.62 \mathrm{~A} \mathrm{~cm}^{-2}$ at $800^{\circ} \mathrm{C}$ under coelectrolysis mode).

\section{Results}

Density functional theory calculations. The complete phase reconstruction from simple perovskite $\left(\mathrm{ABO}_{3}\right)$ to R-P perovskite $\left(\mathrm{A}_{2} \mathrm{BO}_{4}\right)$ via reduction is considered as one of the efficient strategies to significantly boost the population of exsolved particles. However, the key factors contributing to the phase reconstruction to R-P perovskite has not been investigated. To determine the unexplored factor for the phase reconstruction for the first time, the Gibbs free energy for oxygen vacancy formation $\left(\mathrm{G}_{v f-O}\right)$ and the oxygen vacancy formation energies $\left(\mathrm{E}_{v f-O}\right)$ from the surface $\mathrm{AO}$ (A-site) and $\mathrm{BO}_{2}$ (B-site) networks were calculated for $\mathrm{Pr}_{0.5} \mathrm{Ba}_{0.5} \mathrm{TO}_{3-\delta}$ and $\mathrm{Pr}_{0.5} \mathrm{Sr}_{0.5} \mathrm{TO}_{3-\delta}(\mathrm{T}=\mathrm{Mn}, \mathrm{Fe}, \mathrm{Co}$, and $\mathrm{Ni})$ perovskite oxides (Fig. 1 and Supplementary Fig. 1) ${ }^{31-34}$. For the perovskite oxides to undergo phase reconstruction without phase decomposition under reducing condition, the $A$-site $G_{v f-O}$ value should be positive (A-site $\mathrm{G}_{v f-O}>0 \mathrm{eV}$ ). Moreover, the B-site $\mathrm{G}_{v f \text { - }}$ $O$ value would be an important factor for determining the type of phase reconstruction. For instance, the B-site $\mathrm{G}_{v f-O}$ should be in the range of about -1.2 to $0 \mathrm{eV}\left(-1.2 \mathrm{eV}<\mathrm{B}\right.$-site $\left.\mathrm{G}_{v f-O}<0 \mathrm{eV}\right)$ to demonstrate complete phase reconstruction to R-P perovskite in the reduction environment. Considering the aforementioned results and the experimental data, only $\mathrm{Pr}_{0.5} \mathrm{Sr}_{0.5} \mathrm{MnO}_{3-\delta}$ (PSM) and $\mathrm{Pr}_{0.5} \mathrm{Sr}_{0.5} \mathrm{FeO}_{3-\delta}$ (A-PBSF50) are the possible candidates for the complete phase reconstruction to R-P perovskite in this study (Supplementary Fig. 2). Among the two potential candidates, we adopted Fe cation as the more suitable B-site cation because of its much superior catalytic activity for fuel oxidation reaction rather than $\mathrm{Mn}$ cation ${ }^{18}$. Accordingly, we systematically analyzed the phase reconstruction tendency of $\operatorname{Pr}_{0.5} \mathrm{Ba}_{0.5-x} \mathrm{Sr}_{x} \mathrm{FeO}_{3-\delta}(x=0$, $0.1,0.2,0.3,0.4$, and 0.5 , abbreviated as PBSF in Supplementary Table 1) materials with respect to different $\mathrm{Ba}^{2+} / \mathrm{Sr}^{2+}$ ratio.

Structural characterization. Before examining the phase reconstruction tendency of PBSF, the crystalline structures after heattreated in two different environmental conditions were analyzed by X-ray diffraction (XRD) and Rietveld refinement profiles (Supplementary Figs. 3, 4 and Supplementary Table 2). The airsintered PBSF are all corresponded to simple perovskite structure without detectable secondary phases. On the other hand, after reduction in $\mathrm{H}_{2}$ atmosphere, the PBSF samples were surprisingly changed to different types of phases depending on the $\mathrm{Sr}^{2+}$ concentration. As shown in Supplementary Fig. $4 \mathrm{~b}, \mathrm{Pr}_{0.5} \mathrm{Ba}_{0.5^{-}}$ $\mathrm{FeO}_{3-\delta}$ (A-PBSF00), $\mathrm{Pr}_{0.5} \mathrm{Ba}_{0.2} \mathrm{Sr}_{0.3} \mathrm{FeO}_{3-\delta} \quad(\mathrm{A}-\mathrm{PBSF} 30)$, and $\mathrm{Pr}_{0.5} \mathrm{Sr}_{0.5} \mathrm{FeO}_{3-\delta}$ (A-PBSF50) were changed to $\mathrm{Pr}_{0.5} \mathrm{Ba}_{0.5} \mathrm{FeO}_{3-\delta}-$ Fe metal \& Pr oxide (R-PBSF00), $\left(\mathrm{Pr}_{0.5} \mathrm{Ba}_{0.2} \mathrm{Sr}_{0.3}\right){ }_{2} \mathrm{FeO}_{4+\delta}-\mathrm{Fe}$ metal (R-PBSF30), and $\left(\mathrm{Pr}_{0.5} \mathrm{Sr}_{0.5}\right)_{2} \mathrm{FeO}_{4+\delta}-\mathrm{Fe}$ metal (RPBSF50), respectively. Only catalytically active Fe metal peaks along with complete phase reconstruction to R-P perovskite are 


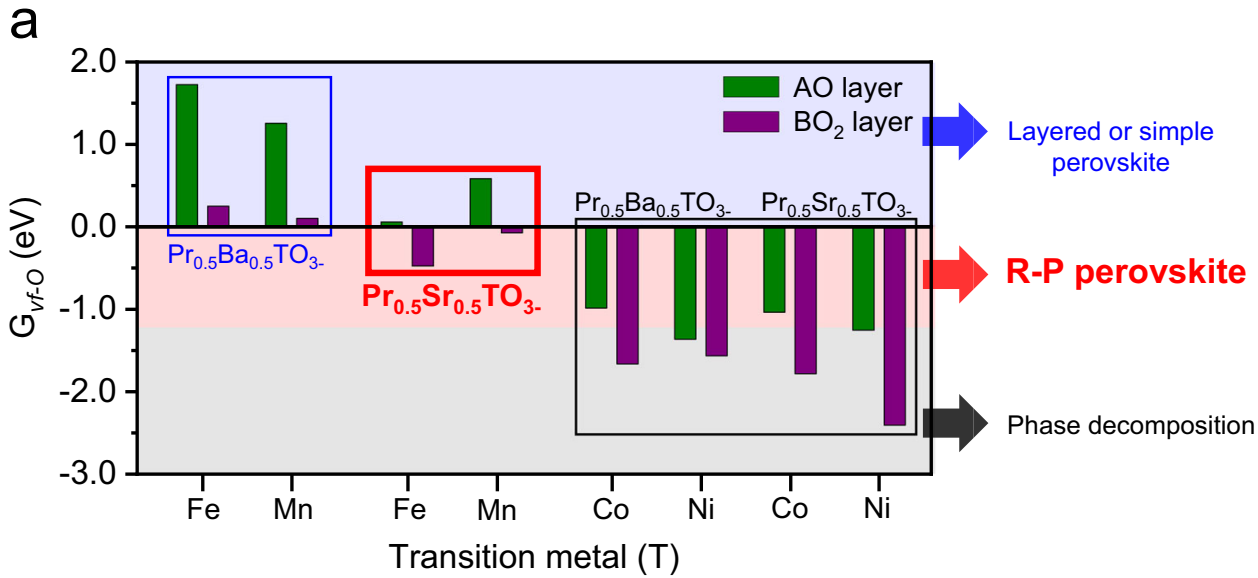

b

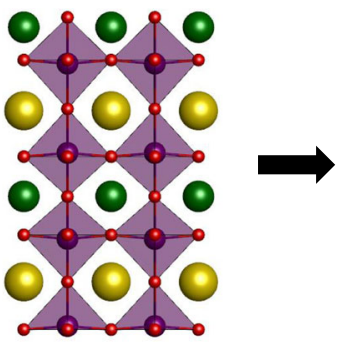

Before oxygen vacancy formation

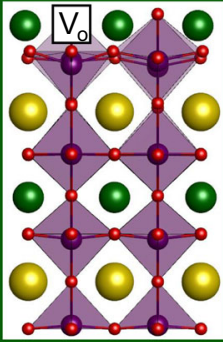

After oxygen vacancy formation from AO layer

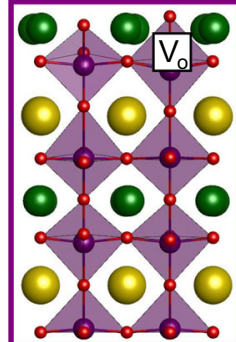

After oxygen vacancy formation from $\mathrm{BO}_{2}$ layer

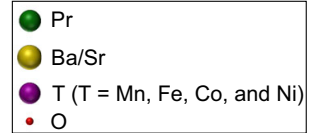

O

(1)

Fig. 1 Density functional theory calculations. a Calculated Gibbs free energy for oxygen vacancy formation $\left(G_{v f-O}\right)$ of $\operatorname{Pr}_{0.5}(B a / S r)_{0.5} T O_{3-\delta}(T=M n, F e$, $\mathrm{Co}$, and $\mathrm{Ni}$ ) from the surface $\mathrm{AO}$ (green bar) and $\mathrm{BO}_{2}$ (purple bar) networks and the predicted phase change under reducing condition. $\mathbf{b}$ Schematic illustration of the most stable structure configurations of $\operatorname{Pr}_{0.5}(\mathrm{Ba} / \mathrm{Sr})_{0.5} \mathrm{TO}_{3-\delta}(\mathrm{T}=\mathrm{Mn}, \mathrm{Fe}, \mathrm{Co}$, and $\mathrm{Ni})$ slab models used for the calculations of oxygen vacancy formation energy values from $\mathrm{AO}$ and $\mathrm{BO}_{2}$ networks.

observed for R-PBSF30 and R-PBSF50, while R-PBSF00 shows Fe metal and $\mathrm{Pr}$ oxide segregation without phase reconstruction under reducing condition. Based on the further Rietveld refinement analysis in Supplementary Fig. 5, R-PBSF30 clearly exhibits the complete phase reconstruction to R-P perovskite with tetragonal structure (space group $\mathrm{I} / \mathrm{mmm}$ with lattice parameters of $\mathrm{a}=\mathrm{b}=3.879$ and $\mathrm{c}=12.704 \AA$ ). The complete phase reconstruction could be also described by Eq. (2), of which considerable amounts of Fe metal are expected to be exsolved in the reduction environment.

$$
\mathrm{Pr}_{0.5} \mathrm{Ba}_{0.2} \mathrm{Sr}_{0.3} \mathrm{FeO}_{3} \underset{\text { After reduction }}{\longrightarrow} \frac{1}{2}\left(\mathrm{Pr}_{0.5} \mathrm{Ba}_{0.2} \mathrm{Sr}_{0.3}\right)_{2} \mathrm{FeO}_{4}+\frac{1}{2} \mathrm{Fe}+\frac{1}{2} \mathrm{O}_{2}
$$

Phase reconstruction tendency analysis from phase diagram. To precisely analyze the phase reconstruction tendency for $\mathrm{Pr}_{0.5} \mathrm{Ba}_{0.5-x} \mathrm{Sr}_{x} \mathrm{FeO}_{3-\delta}(x=0,0.1,0.2,0.25,0.3,0.4$, and 0.5$)$ materials, in-situ XRD measurements were systematically conducted in various reduction temperatures and $\mathrm{Sr}^{2+}$ concentrations. (Fig. 2a and Supplementary Fig. 6). Figure 2b displays the proposed phase diagram and the corresponding plotted points after in-situ XRD measurements in $\mathrm{H}_{2}$ with elevating temperature intervals of $10^{\circ} \mathrm{C}$. The A-PBSF00 sample remained simple perovskite structure for all reduction temperature range and co-segregation of Fe metal and Pr oxide was observed simultaneously at the reduction temperature higher than $840^{\circ} \mathrm{C}$ (Region II in Fig. 2b). Even though there was noticeable phase reconstruction for all $\mathrm{Sr}^{2+}$-doped samples, complete phase reconstruction to $\mathrm{R}-\mathrm{P}$ perovskite was not accomplished for $\mathrm{Pr}_{0.5} \mathrm{Ba}_{0.4} \mathrm{Sr}_{0.1} \mathrm{FeO}_{3-\delta} \quad$ (A-PBSF10), $\mathrm{Pr}_{0.5} \mathrm{Ba}_{0.3} \mathrm{Sr}_{0.2} \mathrm{FeO}_{3-\delta}$ (A-PBSF20), and $\mathrm{Pr}_{0.5} \mathrm{Ba}_{0.25} \mathrm{Sr}_{0.25} \mathrm{FeO}_{3-\delta}$ (A-PBSF25) even at the reduction temperature of $870{ }^{\circ} \mathrm{C}$. (Region III in Fig. 2b). On the contrary, complete phase reconstruction to R-P perovskite is observed for A-PBSF30, $\mathrm{Pr}_{0.5} \mathrm{Ba}_{0.1} \mathrm{Sr}_{0.4} \mathrm{FeO}_{3-\delta}$ (A-PBSF40), and A-PBSF50 at the reduction temperature of approximately $850{ }^{\circ} \mathrm{C}$ (Region IV in Fig. 2b). These results indicate that the ' $x$ ' value in PBSF should be at least approximately 0.3 along with the reduction temperature of about $850{ }^{\circ} \mathrm{C}$ to accomplish complete phase reconstruction, as illustrated in Fig. 2c.

Effect of $\mathrm{Sr}^{2+}$ concentration on phase reconstruction and exsolution. The role of $\mathrm{Sr}^{2+}$ concentration in PBSF in terms of phase reconstruction tendency to R-P perovskite was additionally explored using density functional theory (DFT) calculations. Figure $2 \mathrm{~d}$ shows the required total energies for the phase reconstruction $\left(\mathrm{E}_{\text {recon }}\right)$ from simple perovskite to R-P perovskite of four model structures with different $\mathrm{Ba}^{2+} / \mathrm{Sr}^{2+}$ ratio. The $\mathrm{E}_{\text {recon }}$ decreases with increasing $\mathrm{Sr}^{2+}$ concentration in PBSF, indicating that the incorporation of $\mathrm{Sr}^{2+}$ into $\mathrm{Ba}^{2+}$ site promotes the phase reconstruction to R-P perovskite (Supplementary Fig. 7). Furthermore, the $\mathrm{E}_{v f-O}$ of four simple perovskite models were calculated in Fig. 2e. More negative $\mathrm{E}_{v f-O}$ value implies easier formation of oxygen vacancies in the reduction environment ${ }^{35}$. The $\mathrm{E}_{v f-O}$ value becomes more negative after doping $\mathrm{Sr}^{2+}$ into $\mathrm{Ba}^{2+}$, revealing that the $\mathrm{Sr}^{2+}$ doping facilitates the formation of oxygen vacancies in the reduction atmosphere. This trend could be 
a

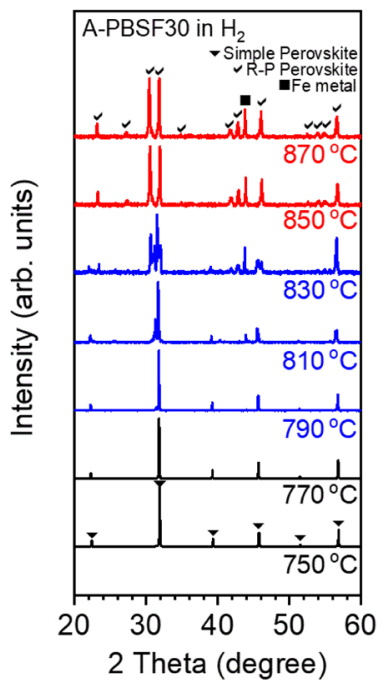

C

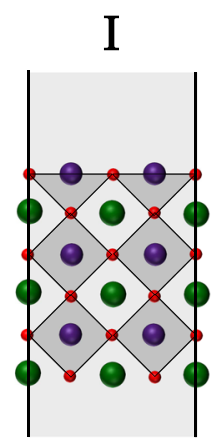

Simple perovskite

A-site (Pr, Ba, Sr)

B-site (Fe)

- Oxygen b

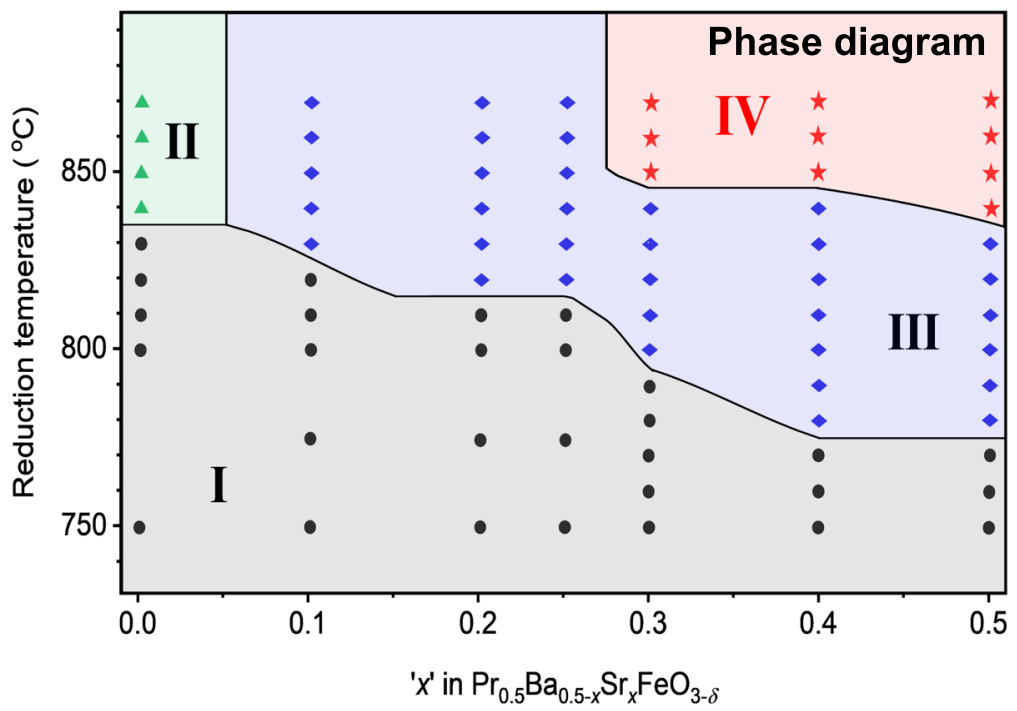

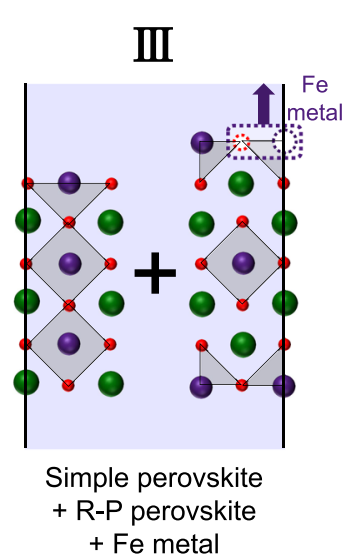

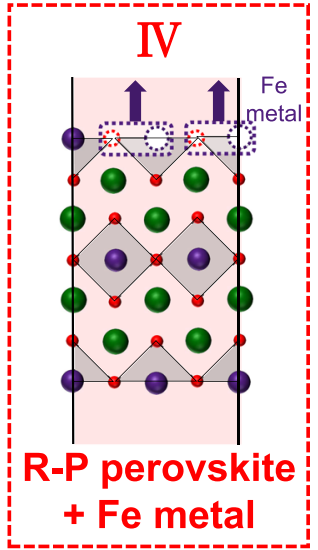

+ Pr oxide

+ Fe metal

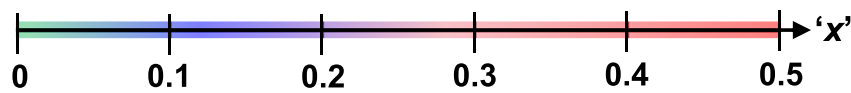

e

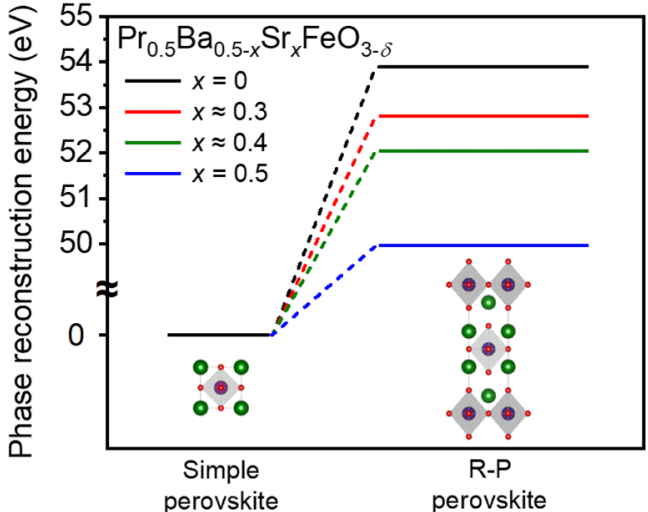

perovskite

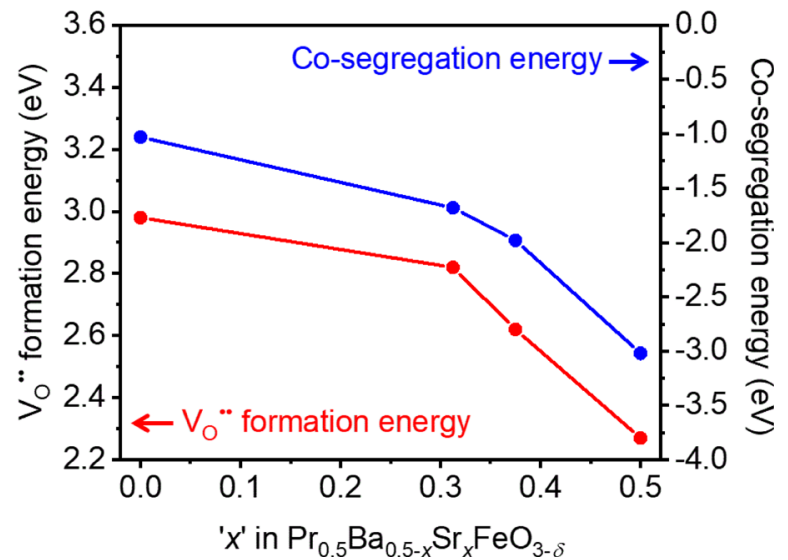

elucidated by the decrease in tolerance factor after replacement of $\mathrm{Ba}^{2+}$ by $\mathrm{Sr}^{2+}$ (Supplementary Table 3$)^{36}$. A co-segregation energy $\left(\mathrm{E}_{\mathrm{co-seg}}\right)$ associated to the degree of exsolution for B-site transition metal cations under reducing condition was also calculated (Fig. 2e). Interestingly, $\mathrm{E}_{\text {co-seg }}$ decreased as the $\mathrm{Sr}^{2+}$ contents increased, suggesting the enhanced degree of $\mathrm{Fe}$ exsolution with increasing $\mathrm{Sr}^{2+}$ concentration.
Transmission electron microscopy analysis. On the basis of proposed phase diagram and DFT calculations, the A-PBSF30, the minimum $\mathrm{Sr}^{2+}$-doped sample demonstrating complete reconstruction to R-P perovskite, is selected as the target material for structural analysis. The transmission electron microscopy (TEM) and scanning TEM (STEM) analysis were successfully performed to visually probe the complete phase reconstruction 
Fig. 2 Examination of phase reconstruction behavior for $\mathbf{P r}_{\mathbf{0 . 5}} \mathbf{B a}_{\mathbf{0 . 5}-\mathbf{x}} \mathbf{S r}_{\mathbf{x}} \mathbf{F e O}_{\mathbf{3}-\delta}$ material under reducing condition. a-c Phase reconstruction tendency of $\mathrm{Pr}_{0.5} \mathrm{Ba}_{0.5-x} \mathrm{Sr}_{x} \mathrm{FeO}_{3-\delta}$ material $\left(x=0,0.1,0.2,0.25,0.3,0.4\right.$, and 0.5). a In-situ powder X-ray diffraction (XRD) patterns of $\mathrm{Pr}_{0.5} \mathrm{Ba}_{0.2} \mathrm{Sr}_{0.3} \mathrm{FeO}_{3-\delta}$ (APBSF30) under $\mathrm{H}_{2}$ environment. b Proposed phase diagram of $\operatorname{Pr}_{0.5} \mathrm{Ba}_{0.5-x} \mathrm{Sr}_{x} \mathrm{FeO}_{3-\delta}$ material $(x=0,0.1,0.2,0.25,0.3,0.4$, and 0.5$)$ in $\mathrm{H}_{2}$ environment as functions of reduction temperature and $\mathrm{Sr}^{2+}$ concentration from in-situ XRD measurements. The phases for region I (gray), II (green), III (blue), and IV (red) are simple perovskite, simple perovskite + Pr oxide + Fe metal, simple perovskite + Ruddlesden-Popper (R-P) perovskite + Fe metal, and R-P perovskite + Fe metal, respectively. c Schematic illustration of the above phase diagram. d, e Density functional theory (DFT) calculations. Calculated profiles of $\mathbf{d}$ the relative total energy required for the phase reconstruction from simple perovskite to R-P perovskite and $\mathbf{e}$ oxygen vacancy formation energies and co-segregation energies as a function of $\mathrm{Sr}^{2+}$ concentration in four models.

from simple perovskite to R-P perovskite of A-PBSF30 material (Fig. 3 and Supplementary Fig. 8). From the high-resolution TEM images and corresponding fast-Fourier transformed (FFT) patterns, the lattice spaces between planes of A-PBSF30 and R-PBSF30 are $0.395 \mathrm{~nm}$ (Fig. 3a) and $0.634 \mathrm{~nm}$ (Fig. 3d), which are consistent with the lattice constant of (001) plane for simple perovskite and the lattice constant of (002) plane for R-P perovskite, respectively. Furthermore, the atomic-scale observations of A-PBSF30 and R-PBSF30 were definitely validated from highangle annular dark-field (HAADF) STEM images, of which only technically elusive [100] direction is mandatory for R-P perovskite. The locations of cations are well-matched with the simple perovskite (Fig. 3b) and R-P perovskite (Fig. 3e) because the atomic column intensity is proportional to the $\mathrm{Z}^{\sim 2}$ ( $\mathrm{Z}$ is the atomic number $)^{37}$, thereby the bright and dark columns are the A-site (i.e., $\mathrm{Pr}, \mathrm{Ba}$, and $\mathrm{Sr}$ (green)) and the B-site (i.e., Fe (purple)), respectively, in the HAADF-STEM mode.

Examination and characterization of exsolved particle size. In general, particle size and surface distribution of catalysts have a considerable influence on the catalytic activity ${ }^{4,38}$. As such, the particle size and surface distribution of exsolved metal particles via reduction treatment could impact on the electro-catalytic activity of catalysts. Before examining the electro-catalytic effect of the in-situ exsolved Fe metal particles, an explicit comparison of exsolved particle size and surface distribution for R-PBSF00, R-PBSF30, and R-PBSF50 samples were presented in scanning electron microscope (SEM) images (Fig. 3c, f and Supplementary Figs. 9, 10). As shown in Fig. 3f, many small particles with size of about 100 to $200 \mathrm{~nm}$ are observed and uniformly socketed onto the perovskite oxide matrix after reduction, which are speculated as Fe metal particles. In contrast, the size of exsolved particles was relatively larger for R-PBSF00 and R-PBSF50 (Supplementary Figs. 11, 12). The energy dispersive spectroscopy (EDS) spectrum and the elemental mapping images of R-PBSF30 also clearly revealed that Fe metal particle with size of about $150 \mathrm{~nm}$ is well-socketed onto the R-P perovskite after reduction (Fig. 3g, h). Furthermore, noticeable energy shift to the higher energy in X-ray absorption near-edge structure (XANES), much increase in Fe-Fe shell intensity from the Fourier-transformed extended X-ray absorption fine structure (EXAFS) spectra after reduction, and the presence of $\mathrm{Fe}^{0} 2 p_{1 / 2}$ peak for only R-PBSF30 from X-ray photoelectron spectroscopy (XPS) measurements confirm the exsolution of $\mathrm{Fe}$ metal onto the surface under reducing condition ${ }^{39}$, in coincidence with the above experimental results (Fig. 4). To investigate the electrically conductive properties of the exsolved Fe metal particles, the electrical conductivities as a function of temperature under reducing atmosphere were measured for PBSF (Supplementary Fig. 13). The A-PBSF30 displayed the highest electrical conductivity value compared to other PBSF in the reduction environment coupled with sufficiently high electrical conductivity in the air atmosphere (Supplementary Fig. 13b ${ }^{40}$, suggesting that the A-PBSF30 is the potential electrode material for S-SOC electrode material.
Electrochemical performance evaluation. Prior to assessment of electrochemical performance for A-PBSF30 in the practical application of S-SOCs, great thermo-chemical compatibility between all PBSF and the $\mathrm{La}_{0.9} \mathrm{Sr}_{0.1} \mathrm{Ga}_{0.8} \mathrm{Mg}_{0.2} \mathrm{O}_{3-\delta}$ (LSGM) electrolyte was confirmed by XRD measurement (Supplementary Fig. 14). Moreover, similar microstructures of air-sintered PBSF samples imply that the electrochemical performance would not be affected by surface morphology (Supplementary Fig. 15). Then, electrochemical performance of symmetrical solid oxide fuel cells (S-SOFCs) using PBSF as both electrodes was characterized by LSGM electrolyte-supported cells to identify the huge impact of the exsolved $\mathrm{Fe}$ metal particle size and surface distribution (Fig. 5a and Supplementary Figs. 16, 17). The peak power density of the A-PBSF30 symmetrical cell is $1.23 \mathrm{~W} \mathrm{~cm}^{-2}$ at $800{ }^{\circ} \mathrm{C}$ with humidified $\mathrm{H}_{2}\left(3 \% \mathrm{H}_{2} \mathrm{O}\right)$ as fuel. This outstanding cell performance is the highest out of open literature based on LSGM electrolyte-supported S-SOFCs without any external catalysts at $800{ }^{\circ} \mathrm{C}$ under humidified $\mathrm{H}_{2}\left(3 \% \mathrm{H}_{2} \mathrm{O}\right)$ as fuel to our best knowledge (Fig. 5b and Table 1) $28,39,41-46$. In addition, peak power output of $0.73 \mathrm{~W} \mathrm{~cm}^{-2}$ was demonstrated in humidified $\mathrm{C}_{3} \mathrm{H}_{8}\left(3 \% \mathrm{H}_{2} \mathrm{O}\right)$ at $800{ }^{\circ} \mathrm{C}$ (Fig. $5 \mathrm{c}$ and Supplementary Fig. 18). Furthermore, the A-PBSF30 symmetrical cell demonstrated fairly stable current density without observable degradation for about $200 \mathrm{~h}$ in $\mathrm{H}_{2}$ and $150 \mathrm{~h}$ in $\mathrm{C}_{3} \mathrm{H}_{8}$ at $700^{\circ} \mathrm{C}$ (Fig. $5 \mathrm{~d}, \mathrm{e}$ ). We also evaluated the electrochemical performance of the A-PBSF30 symmetrical cell in co-electrolysis mode. The excellent current density of $-1.62 \mathrm{~A} \mathrm{~cm}^{-2}$ at a cell voltage of $1.5 \mathrm{~V}$ (close to thermo-neutral voltage $)^{47}$ at $800^{\circ} \mathrm{C}$ under co-electrolysis condition was demonstrated for the A-PBSF30 symmetrical cell (Fig. 5f), which is exceptionally high compared to other oxygenconducting solid oxide electrolysis cell (SOEC) systems with different electrode materials ${ }^{19,31,48,49}$. The in-operando quantitative analysis of the synthetic gas products $\left(\mathrm{H}_{2}\right.$ and $\left.\mathrm{CO}\right)$ was further investigated via gas chromatography (GC) profiles for the A-PBSF30 symmetrical cell at $800{ }^{\circ} \mathrm{C}$ during co-electrolysis of $\mathrm{H}_{2} \mathrm{O}$ and $\mathrm{CO}_{2}$ (Supplementary Fig. 19). The amount of generated $\mathrm{H}_{2}$ and $\mathrm{CO}$ were measured to be 0.50 and $10.81 \mathrm{ml} \mathrm{min}^{-1} \mathrm{~cm}^{-2}$, respectively, implying that the A-PBSF30 symmetrical cell could efficiently produce synthetic gas during co-electrolysis ${ }^{50}$. Together with superior electrochemical performance and efficient synthetic gas production, relatively constant voltage was observed for $100 \mathrm{~h}$ under a constant current load of $-0.25 \mathrm{~A} \mathrm{~cm}^{-2}$ at $700{ }^{\circ} \mathrm{C}$ in co-electrolysis mode (Fig. $5 \mathrm{~g}$ ), representing great durability in continuous SOEC operation. It is noteworthy that in-situ exsolution of well-dispersed $\mathrm{Fe}$ metal particles after complete phase reconstruction to R-P perovskite matrix acts as catalysts with promising electro-catalytic activity (Fig. 6), leading to outstanding electrochemical performances in various applications.

\section{Discussion}

In summary, this study successfully calculated $\mathrm{G}_{v f-O}$ value from PrO and $\mathrm{TO}_{2}$ in $\operatorname{Pr}_{0.5}(\mathrm{Ba} / \mathrm{Sr})_{0.5} \mathrm{TO}_{3-\delta}(\mathrm{T}=\mathrm{Mn}, \mathrm{Fe}, \mathrm{Co}$, and $\mathrm{Ni})$ as the key factor for identifying the type of the phase reconstruction. Remarkably, the phase diagram acquired from in-situ 


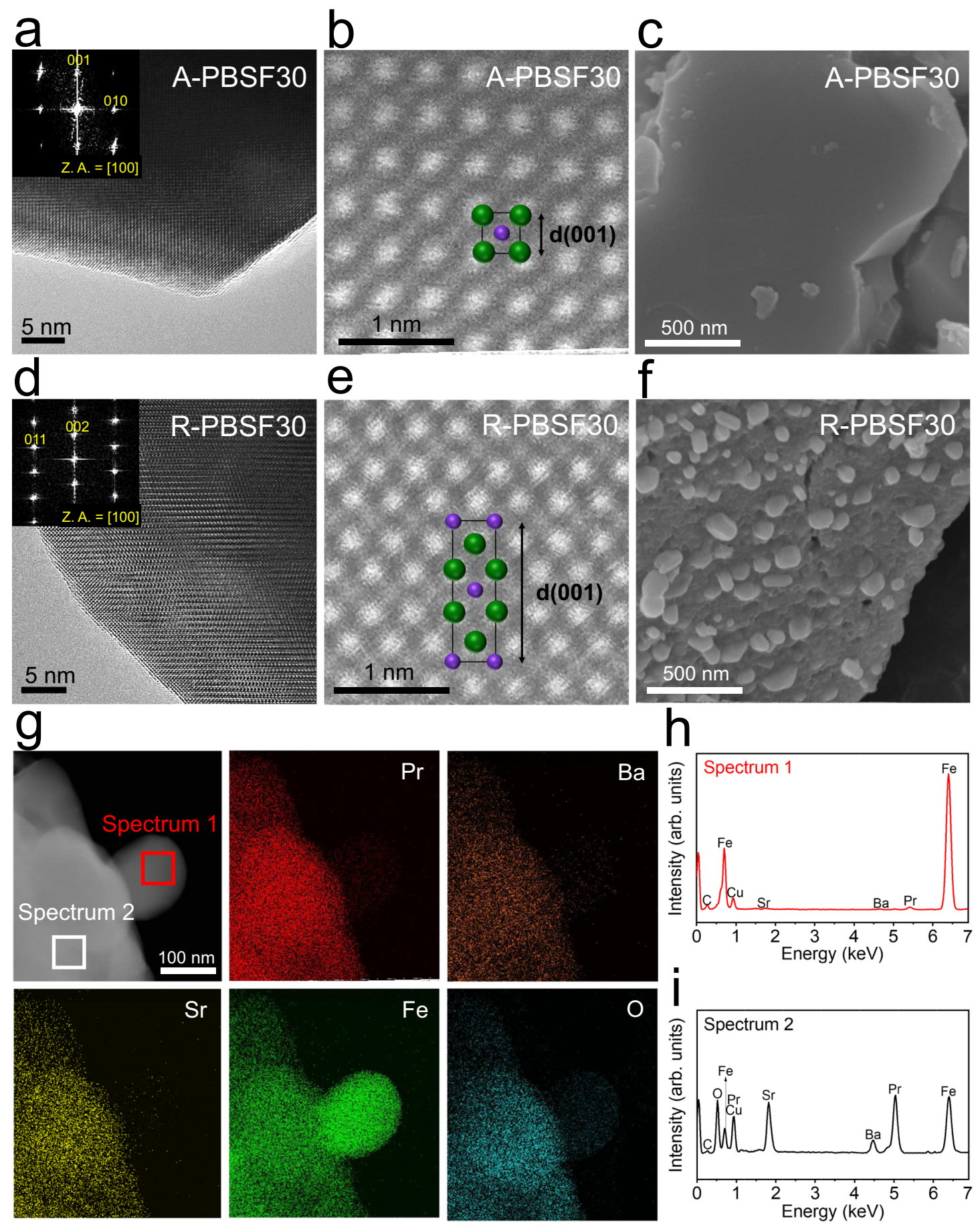

Fig. 3 Electron microscopic analysis. a, b, d, e Transmission electron microscopy (TEM) analysis. a High-resolution (HR) TEM image and the corresponding fast-Fourier transformed (FFT) pattern of $\operatorname{Pr}_{0.5} \mathrm{Ba}_{0.2} \mathrm{Sr}_{0.3} \mathrm{FeO}_{3-\delta}$ (A-PBSF30) with zone axis (Z.A.) $=[100]$ and $\mathbf{b}$ high-angle annular darkfield (HAADF) scanning TEM (STEM) image of A-PBSF30 with simple perovskite structure of [100] direction with d-spacing 001. $\mathbf{d}$ HR TEM image and the corresponding FFT pattern of $\left(\operatorname{Pr}_{0.5} \mathrm{Ba}_{0.2} \mathrm{Sr}_{0.3}\right)_{2} \mathrm{FeO}_{4+\delta}-\mathrm{Fe}$ metal (R-PBSF30) with Z.A. $=[100]$ and e HAADF STEM image and the atomic arrangement of R-PBSF30 of [100] direction with d-spacing 001. c, f Scanning electron microscope (SEM) images. SEM images presenting the surface morphologies of $\mathbf{c}$ A-PBSF30 sintered at $1200^{\circ} \mathrm{C}$ for $4 \mathrm{~h}$ in air atmosphere and $\mathbf{f}$ R-PBSF30 reduced at $850^{\circ} \mathrm{C}$ for $4 \mathrm{~h}$ in humidified $\mathrm{H}_{2}$ environment ( $3 \% \mathrm{H}_{2} \mathrm{O}$ ). $\mathbf{g}$-i Scanning TEM-energy dispersive spectroscopy (EDS) analysis. $\mathbf{g}$ HAADF image of R-PBSF30 and elemental mapping of $\mathrm{Pr}, \mathrm{Ba}$, $\mathrm{Sr}$, Fe, and O, respectively. $\mathbf{h}$, $\mathbf{i}$ EDS spectra of $\mathbf{h}$ the exsolved Fe metal particle (Spectrum 1, red) and $\mathbf{i}$ the parent material $\left(\operatorname{Pr}_{0.5} \mathrm{Ba}_{0.2} \mathrm{Sr}_{0.3}\right)_{2} \mathrm{FeO}{ }_{4+\delta}$ (Spectrum 2, black).

temperature and environment-controlled XRD measurements indicated that the complete phase reconstruction to R-P perovskite occurs at least approximately $x=0.3$ above at the reduction temperature of $850^{\circ} \mathrm{C}$ for PBSF system. Among PBSF with complete phase reconstruction, the highly-populated $\mathrm{Fe}$ metal particles socketed on R-PBSF30 attributed to excellent electrochemical performances under both fuel cell $\left(1.23 \mathrm{~W} \mathrm{~cm}^{-2}\right.$ at $800{ }^{\circ} \mathrm{C}$ under $\mathrm{H}_{2}$ fuel $)$ and electrolysis cell $\left(-1.62 \mathrm{~A} \mathrm{~cm}^{-2}\right.$ at $1.5 \mathrm{~V}$ and $800^{\circ} \mathrm{C}$ under $\mathrm{CO}_{2}$ and $\mathrm{H}_{2} \mathrm{O}$ fuels) modes coupled with great durability. Our investigations strongly provide a pathway to 
a

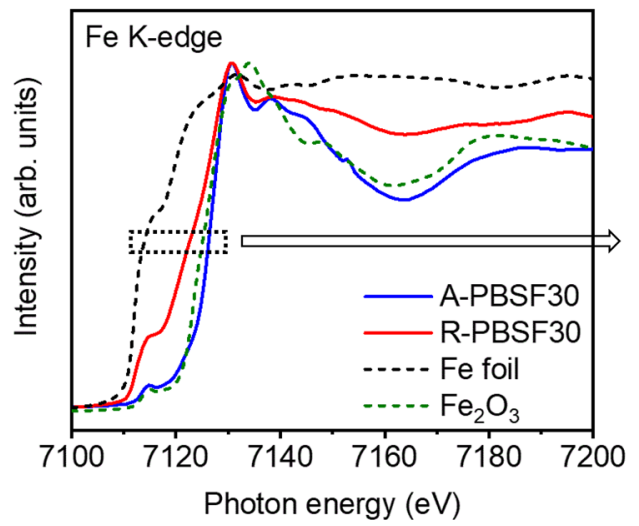

b
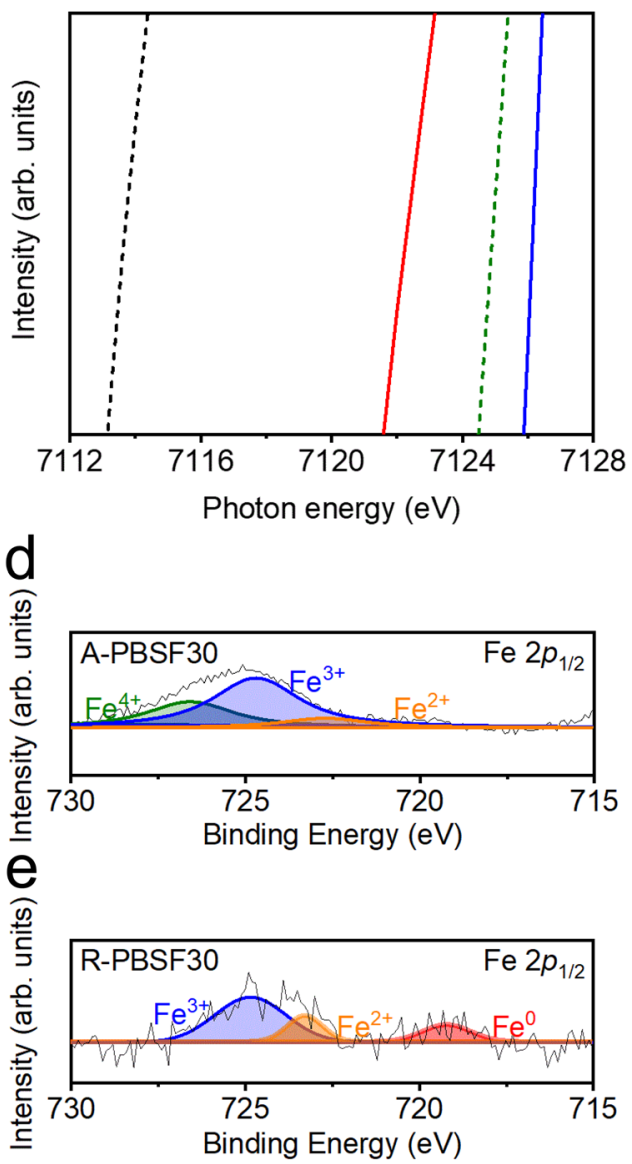

Fig. 4 Oxidation state characterization. a, b Fe K-edge X-ray absorption near-edge structure (XANES) spectra of $\operatorname{Pr}_{0.5} \mathrm{Ba}_{0.2} \mathrm{Sr}_{0.3} \mathrm{FeO}_{3-\delta}$ (A-PBSF30), $\left(\mathrm{Pr}_{0.5} \mathrm{Ba}_{0.2} \mathrm{Sr}_{0.3}\right)_{2} \mathrm{FeO}_{4+\delta}$ (R-PBSF30) with two references (Fe foil and $\mathrm{Fe}_{2} \mathrm{O}_{3}$ ). c Fourier-transformed Fe K-edge extended $\mathrm{X}$-ray absorption fine structure (EXAFS) spectra of A-PBSF30 and R-PBSF30. X-ray photoelectron spectra (XPS) of Fe 2p $p_{1 / 2}$ for d A-PBSF30 and e R-PBSF30.

explore new factors for the phase reconstruction and offer a new opportunity to discover prospective candidates with customized functionalities for next-generation energy-related applications.

\section{Methods}

Material synthesis. $\mathrm{Pr}_{0.5} \mathrm{Ba}_{0.5-x} \mathrm{Sr}_{x} \mathrm{FeO}_{3-\delta}$ samples $(x=0,0.1,0.2,0.3,0.4$, and 0.5 , abbreviated as PBSF in Supplementary Table 1) and $\operatorname{Pr}_{0.5} \mathrm{Sr}_{0.5} \mathrm{MnO}_{3-\delta}$ were synthesized by the Pechini method. For PBSF materials, stoichiometric amounts of $\mathrm{Pr}\left(\mathrm{NO}_{3}\right)_{3} \cdot 6 \mathrm{H}_{2} \mathrm{O}$ (Aldrich, 99.9\%, metal basis), $\mathrm{Ba}\left(\mathrm{NO}_{3}\right)_{2}$ (Aldrich, $99+\%$ ), $\mathrm{Sr}\left(\mathrm{NO}_{3}\right)_{2}$ (Aldrich, $99+\%$ ) and $\mathrm{Fe}\left(\mathrm{NO}_{3}\right)_{3} \cdot 9 \mathrm{H}_{2} \mathrm{O}$ (Aldrich, 98+\%) nitrate salts were dissolved in distilled water with the addition of quantitative amounts of citric acid and poly-ethylene glycol, while for $\operatorname{Pr}_{0.5} \mathrm{Sr}_{0.5} \mathrm{MnO}_{3-\delta}$ material, stoichiometric amounts of $\operatorname{Pr}\left(\mathrm{NO}_{3}\right)_{3} \cdot 6 \mathrm{H}_{2} \mathrm{O}$ (Aldrich, 99.9\%, metal basis), $\mathrm{Sr}\left(\mathrm{NO}_{3}\right)_{2}$ (Aldrich, 99+ $\%)$ and $\mathrm{Mn}\left(\mathrm{NO}_{3}\right)_{2} \cdot 4 \mathrm{H}_{2} \mathrm{O}$ (Aldrich, 97+\%) nitrate salts were dissolved in distilled water with the addition of quantitative amounts of citric acid and poly-ethylene glycol. After removal of excess resin by heating at $280^{\circ} \mathrm{C}$, transparent organic resins containing metals in a solid solution were formed. The resins were calcined at $600{ }^{\circ} \mathrm{C}$ for $4 \mathrm{~h}$ and then sintered at $1200^{\circ} \mathrm{C}$ for $4 \mathrm{~h}$ in air environment. The chemical compositions of the synthesized powders and their abbreviations are given in Supplementary Table 1.

Structural characterization. The crystal structures of the $\mathrm{Pr}_{0.5} \mathrm{Ba}_{0.5-x} \mathrm{Sr}_{x} \mathrm{FeO}_{3-\delta}$ samples $(x=0,0.3$, and 0.5$)$ and $\mathrm{Pr}_{0.5} \mathrm{Sr}_{0.5} \mathrm{MnO}_{3-\delta}$ after heat-treated in two different environmental conditions (sintered at $1200^{\circ} \mathrm{C}$ for $4 \mathrm{~h}$ in air environment and reduced at $850{ }^{\circ} \mathrm{C}$ for $4 \mathrm{~h}$ in humidified $\mathrm{H}_{2}$ environment $\left(3 \% \mathrm{H}_{2} \mathrm{O}\right)$ ) were first identified by powder XRD patterns (Bruker diffractometer (LYNXEYE $1 \mathrm{D}$ detector), $\mathrm{Cu} \mathrm{K \alpha}$ radiation, $40 \mathrm{kV}, 40 \mathrm{~mA}$ ) in the 2 theta range of $20^{\circ}<2 \theta<60^{\circ}$. To calculate the exact Bravais lattice of the PBSF, the samples were first pressed into pellets at $2 \mathrm{MPa}$ for $30 \mathrm{~s}$ and then sintered at $1200^{\circ} \mathrm{C}$ for $4 \mathrm{~h}$ in air atmosphere. The XRD patterns of air-sintered PBSF series and $\left(\mathrm{Pr}_{0.5} \mathrm{Ba}_{0.2} \mathrm{Sr}_{0.3}\right)_{2} \mathrm{FeO}_{4+\delta}-\mathrm{Fe}$ metal (R-PBSF30) samples were further measured by high-power (HP) XRD. (Max $2500 \mathrm{~V}, \mathrm{Cu} K \alpha$ radiation, $40 \mathrm{kV}, 200 \mathrm{~mA}$ ) at a scanning rate of $1^{\circ} \mathrm{min}^{-1}$ and a range of $15^{\circ}<2 \theta<105^{\circ}$. After the HP XRD measurement, the powder patterns and lattice parameters were analyzed by the Rietveld refinement technique using the GSAS II program. The surface analysis of $\mathrm{Pr}_{0.5} \mathrm{Ba}_{0.2} \mathrm{Sr}_{0.3} \mathrm{FeO}_{3-\delta}$ (A-PBSF30) sintered at $1200^{\circ} \mathrm{C}$ for $4 \mathrm{~h}$ in air atmosphere and $\left(\mathrm{Pr}_{0.5} \mathrm{Ba}_{0.2} \mathrm{Sr}_{0.3}\right)_{2} \mathrm{FeO}_{4+\delta}-\mathrm{Fe}$ metal (R-PBSF30) reduced at $850^{\circ} \mathrm{C}$ for $4 \mathrm{~h}$ in humidified $\mathrm{H}_{2}$ environment $\left(3 \% \mathrm{H}_{2} \mathrm{O}\right)$ were conducted on XPS analyses on ESCALAB 250 XI from

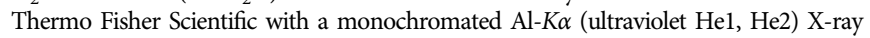
source. The X-ray absorption fine structure (XAFS) spectra of Fe K-edge for A-PBSF30, R-PBSF30, and two references ( $\mathrm{Fe}$ foil and $\mathrm{Fe}_{2} \mathrm{O}_{3}$ powder) were measured on ionization detectors under fluorescence mode at the Pohang Accelerator Laboratory (PAL, 6D extended XAFS (EXAFS)). The XAFS and Fourier-transformed (FT) EXAFS spectra analysis were performed using the Athena (Demeter) program.

In-situ phase reconstruction tendency evaluation. The in-situ phase reconstruction tendency of $\mathrm{Pr}_{0.5} \mathrm{Ba}_{0.5-x} \mathrm{Sr}_{x} \mathrm{FeO}_{3-\delta}(x=0,0.1,0.2,0.25,0.3,0.4$, and 0.5$)$ samples were identified by in-situ XRD measurements under humidified $\mathrm{H}_{2}$ condition ( $3 \%$ $\mathrm{H}_{2} \mathrm{O}$ ). The $\mathrm{Pr}_{0.5} \mathrm{Ba}_{0.25} \mathrm{Sr}_{0.25} \mathrm{FeO}_{3-\delta}$ (A-PBSF25) sample was additionally synthesized by the Pechini method to evaluate the phase reconstruction tendency under reducing atmosphere. The $\operatorname{Pr}_{0.5} \mathrm{Ba}_{0.5-} \mathrm{Sr}_{x} \mathrm{FeO}_{3-\delta}(x=0,0.1,0.2,0.25,0.3,0.4$, and 0.5$)$ samples were sintered at $1200^{\circ} \mathrm{C}$ for $4 \mathrm{~h}$ in air atmosphere to form simple perovskite structure with fine crystallinity. The reduction temperatures were ranged from 700 to $870{ }^{\circ} \mathrm{C}$ and $2 \mathrm{~h}$ were delayed at each temperature interval (Bruker D8 advance).

Electron microscopy analysis. The microstructures of (1) $\mathrm{Pr}_{0.5} \mathrm{Ba}_{0.5-x} \mathrm{Sr}_{x} \mathrm{FeO}_{3-\delta}$ samples $(x=0,0.3$, and 0.5$)$ sintered at $1200^{\circ} \mathrm{C}$ for $4 \mathrm{~h}$ in air atmosphere, (2) $\mathrm{Pr}_{0.5} \mathrm{Ba}_{0.5-x} \mathrm{Sr}_{x} \mathrm{FeO}_{3-\delta}$ samples $(x=0,0.3$, and 0.5$)$ reduced at $850^{\circ} \mathrm{C}$ for $4 \mathrm{~h}$ in humidified $\mathrm{H}_{2}$ environment $\left(3 \% \mathrm{H}_{2} \mathrm{O}\right)$, and (3) all PBSF samples sintered at $950{ }^{\circ} \mathrm{C}$ for $4 \mathrm{~h}$ in air atmosphere were investigated by using an SEM (Nova Nano FE-SEM). TEM analyses were conducted with a JEOL JEM $2100 \mathrm{~F}$ with a probe forming (STEM) Cs (spherical aberration) corrector at $200 \mathrm{kV}$.

Electrical conductivity measurements. The electrical conductivities of PBSF with respect to temperature were measured under air and $5 \% \mathrm{H}_{2}$ environments by the 
a
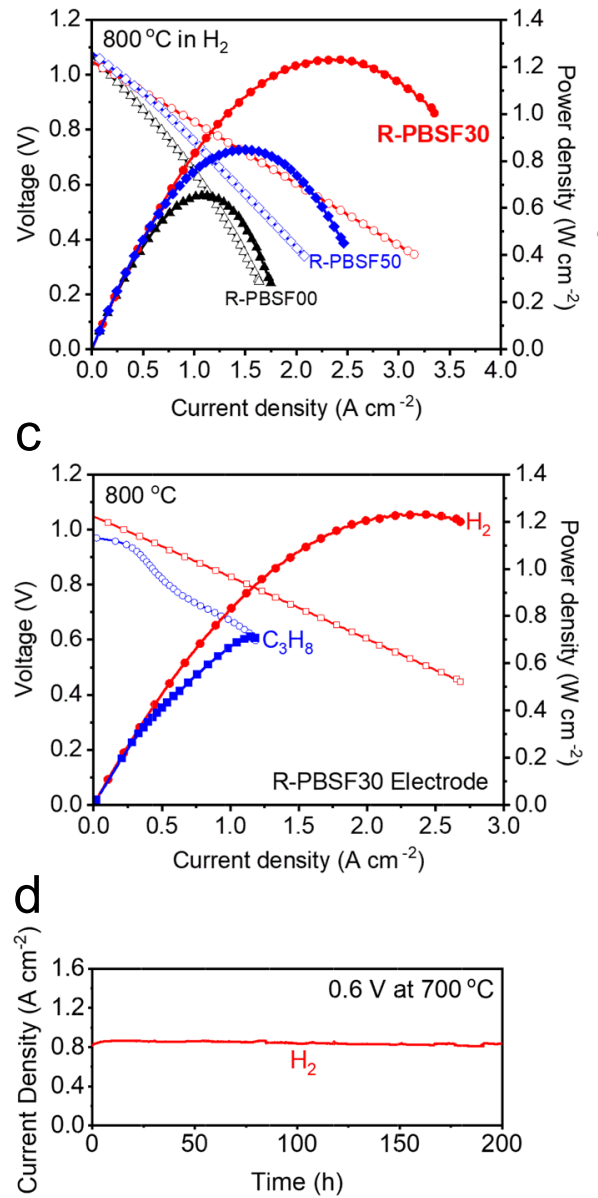

f

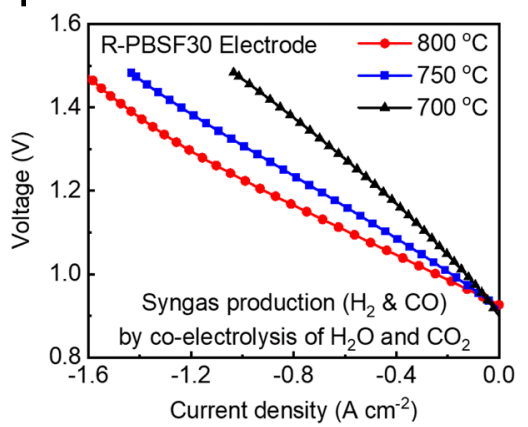

$\mathrm{b}$

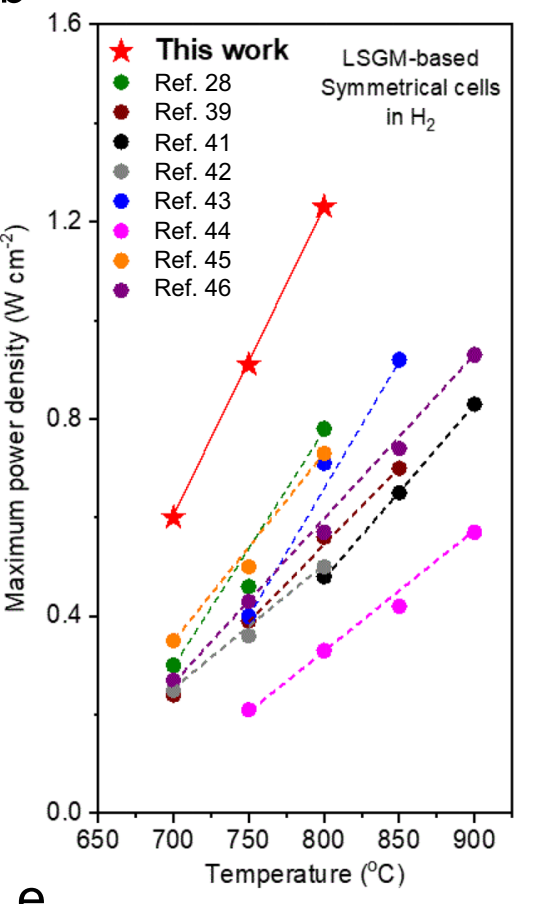

e

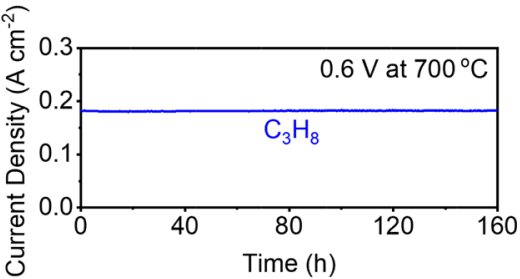

g

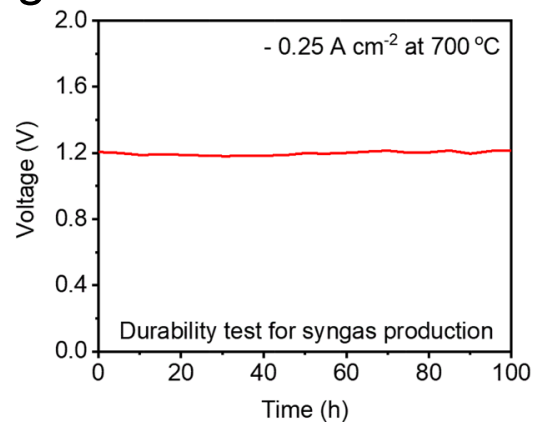

Fig. 5 Electrochemical performance measurements. a, b Comparison of the maximum power density values at $800{ }^{\circ} \mathrm{C}$ in $\mathrm{H}_{2}$. (a) in terms of $\mathrm{Pr}_{0.5} \mathrm{Ba}_{0.5-x} \mathrm{Sr}_{x} \mathrm{FeO}_{3-\delta}$ compositions $(x=0,0.3$, and 0.5 ) and $\mathbf{b}$ of the present work and other LSGM electrolyte-supported studies with symmetrical cell configuration at various temperature regimes. c I-V curves and the corresponding power densities of symmetrical cell with $\left(\mathrm{Pr}_{0.5} \mathrm{Ba}_{0.2} \mathrm{Sr}_{0.3}\right)_{2} \mathrm{FeO}_{4+\delta}-\mathrm{Fe}_{3}$ metal (R-PBSF30) fuel electrode at $800{ }^{\circ} \mathrm{C}$ under $\mathrm{H}_{2}$ and $\mathrm{C}_{3} \mathrm{H}_{8}$ humidified fuels $\left(3 \% \mathrm{H}_{2} \mathrm{O}\right.$ ) fed on the fuel electrode and air fed on the air electrode. d, e Durability test of symmetrical cell with R-PBSF30 fuel electrode recorded with respect to time at a constant voltage of $0.6 \mathrm{~V}$ at $700{ }^{\circ} \mathrm{C}$ under $\mathbf{d} \mathrm{H}_{2}$ and e $\mathrm{C}_{3} \mathrm{H}_{8}$ humidified fuels. $\mathbf{f} \mathrm{I}-\mathrm{V}$ curves for symmetrical cell with R-PBSF30 fuel electrode with humidified $\mathrm{H}_{2}$ and $\mathrm{CO}_{2}$ with $\mathrm{H}_{2} \mathrm{O}$ co-fed to the fuel electrode side and air fed to the air electrode. $\mathbf{g}$ Durability test of symmetrical cell with R-PBSF30 fuel electrode recorded at a constant current of $-0.25 \mathrm{Acm}{ }^{-2}$ at $700{ }^{\circ} \mathrm{C}$ during co-electrolysis for $100 \mathrm{~h}$.

4-probe method. The samples were pressed into pellets of cylindrical shape and then sintered at $1400^{\circ} \mathrm{C}$ for $4 \mathrm{~h}$ in air environment to reach an apparent density of $\sim 90 \%$. The electrical conductivities were first measured in air atmosphere from 300 to $800{ }^{\circ} \mathrm{C}$ with intervals of $50^{\circ} \mathrm{C}$, and then measured in wet $5 \% \mathrm{H}_{2}$ atmosphere ( $\mathrm{Ar}$ balance, $3 \% \mathrm{H}_{2} \mathrm{O}$ ) from 300 to $800^{\circ} \mathrm{C}$ with intervals of $50{ }^{\circ} \mathrm{C}$. The current and voltage were recorded by a Biologic Potentiostat to calculate the resistance, resistivity, and conductivity of samples.

Computational methods. DFT calculations were performed to investigate the appropriate dopants for the phase reconstruction to $\mathrm{n}=1 \mathrm{R}-\mathrm{P}$ perovskite along with the role of $\mathrm{Sr}^{2+}$ concentration on phase reconstruction tendency of PBSF using the Vienna $\mathrm{ab}$ initio Simulation Package ${ }^{51,52}$. For the exchange-correlation, the generalized gradient approximation (GGA) based Predew-Burke-Ernzerhof functional was used ${ }^{53}$. The electron-ion interactions were described using the projector augmented wave potential ${ }^{54,55}$. A plane wave was expanded up to cutoff energy of $400 \mathrm{eV}$. Electronic occupancies were calculated using Gaussian smearing with a smearing parameter of $0.05 \mathrm{eV}$. For the bulk optimization, all internal atoms were relaxed using a conjugate gradient algorithm until the forces of each atom were lowered below $0.03 \mathrm{eV} / \mathrm{A}$ with an energy convergence of $10^{-5} \mathrm{eV}$. GGA $+U$ approach was used to correct the selfinteraction errors with $U_{\text {eff }}=4.0 \mathrm{eV}$ for Fe $3 \mathrm{~d}$ orbital, $U_{\text {eff }}=3.3 \mathrm{eV}$ for Co $3 \mathrm{~d}$ orbital, 
Table 1 Comparison of the electrochemical performance of $\mathrm{La}_{1-x} \mathrm{Sr}_{x} \mathrm{Ga}_{1-y} \mathrm{Mg}_{y} \mathrm{O}_{3-\delta}$ (LSGM) electrolyte-supported symmetrical solid oxide fuel cells (S-SOFCs) reported in the literature and in the present study.

\begin{tabular}{|c|c|c|c|}
\hline Reference & Cell configuration (Air electrode | Electrolyte | Fuel electrode) & $\begin{array}{l}\text { Electrolyte } \\
\text { thickness }(\mu \mathrm{m})\end{array}$ & $\begin{array}{l}\text { Maximum power } \\
\text { density at } 800^{\circ} \mathrm{C} \\
\left(\mathrm{W} \mathrm{cm}^{-2}\right)\end{array}$ \\
\hline $\begin{array}{l}\text { Present study } \\
(28) \\
(39) \\
(41) \\
(42) \\
(43) \\
(44) \\
(45) \\
(46)\end{array}$ & 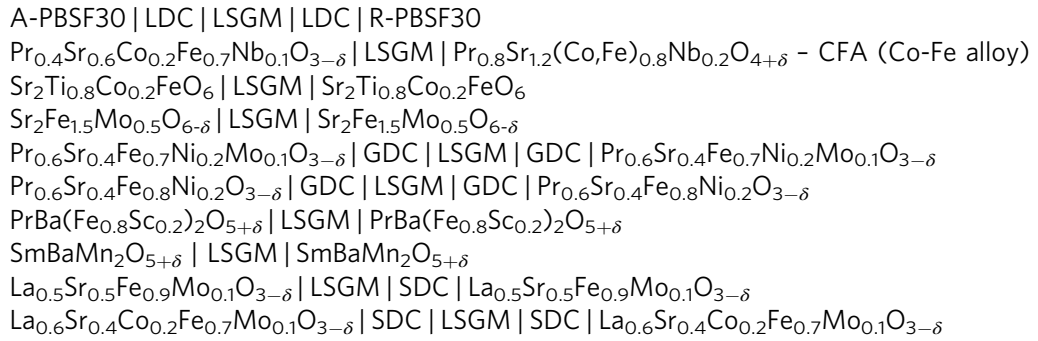 & $\begin{array}{l}\sim 250 \\
\sim 300 \\
\sim 270 \\
\sim 265 \\
\sim 320 \\
\sim 320 \\
\sim 275 \\
\sim 300 \\
\sim 300 \\
\sim 270\end{array}$ & $\begin{array}{l}1.23 \\
0.78 \\
0.56 \\
0.48 \\
0.50 \\
0.44 \\
0.71 \\
0.33 \\
0.73 \\
0.74\end{array}$ \\
\hline
\end{tabular}
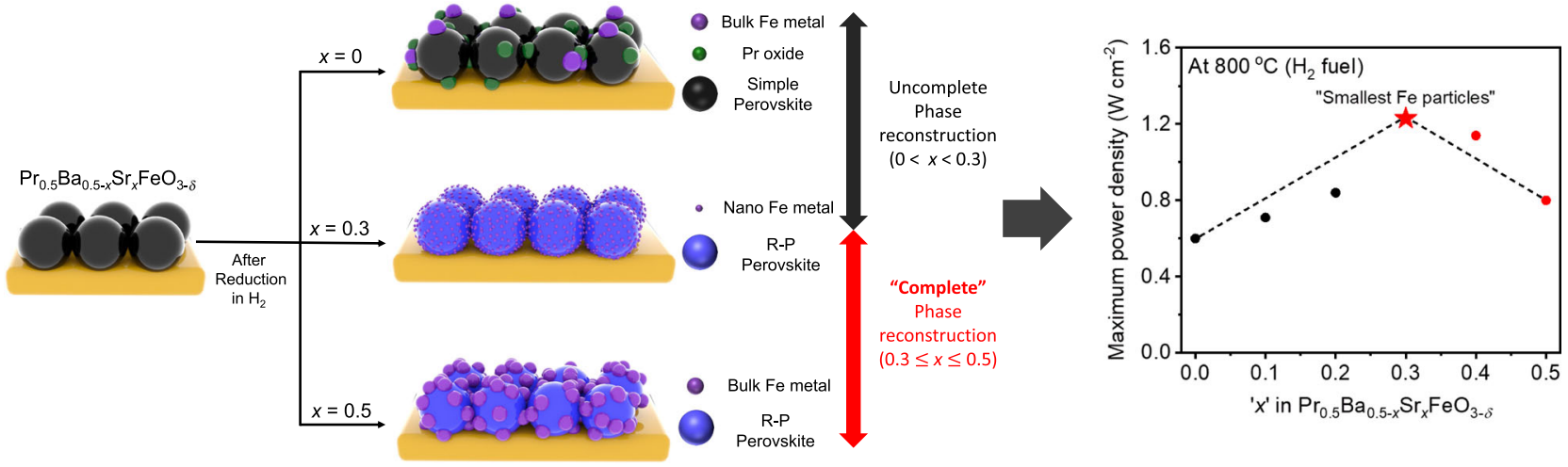

Fig. 6 Schematic illustration of this work. Schematic illustration of the fuel electrode side of $\operatorname{Pr}_{0.5} \mathrm{Ba}_{0.5-x} \mathrm{Sr}_{x} \mathrm{FeO}_{3-\delta}(x=0,0.3$, and 0.5$)$ symmetrical cells and its relation to electrochemical performances.

$U_{\text {eff }}=4.0 \mathrm{eV}$ for Mn 3d orbital, $U_{\text {eff }}=7.0 \mathrm{eV}$ for Ni 3d orbital, and $U_{\text {eff }}=6.0 \mathrm{eV}$ for $\operatorname{Pr}$ 4f orbital $18,56,57$. For the Brillouin zones of the formation energy calculation of cubic perovskite $(2 \times 2 \times 4$ super cell) and $n=1$ R-P perovskite $(2 \times 2 \times 1$ super cell), $3 \times 3 \times 1$ and $3 \times 3 \times 2$ Monkhorst-Pack k-point sampling were used, respectively ${ }^{58}$. For the oxygen vacancy formation energy calculations of $\mathrm{BO}_{2}$ layer between two $\mathrm{AO}$ layers, PrO-terminated (001) slab model $(2 \times 2$ surface, 8 layers with 2 fixed bottom layers, vacuum layer of $16 \AA$ ) were used. For the co-segregation energy calculations, $\mathrm{FeO}_{2}$ terminated (001) slab model $(2 \sqrt{ } 2 \times 2 \sqrt{ } 2$ surface, 8 layers with 3 fixed bottom layers, vacuum layer of $16 \AA$ ) were used. For the Brillouin zones of the oxygen vacancy formation energy and the co-segregation energy calculations, $3 \times 3 \times 1$ and $1 \times 1 \times 1$ Monkhorst-Pack k-point sampling were used. The optimized lattice parameters of four materials, A-PBSF00 (Ba:Sr $=16: 0), \mathrm{Pr}_{05} \mathrm{Ba}_{0.1875} \mathrm{Sr}_{03125} \mathrm{FeO}_{3-\delta}(\mathrm{Ba}: \mathrm{Sr}=6: 10)$, $\mathrm{Pr}_{0.5} \mathrm{Ba}_{0.125} \mathrm{Sr}_{0.375} \mathrm{FeO}_{3-\delta}(\mathrm{Ba}: \mathrm{Sr}=4: 12)$, and A-PBSF50 (Ba:Sr $\left.=0: 16\right)$ were used for model structures in the computational studies. For the $\mathrm{Ba}^{2+} / \mathrm{Sr}^{2+}$ mixed models, the most stable configurations among the total 5 different $\mathrm{Ba}$ configurations were used.

The relative energies required for the phase reconstruction from simple perovskite to $\mathrm{n}=1 \mathrm{R}-\mathrm{P}$ perovskite $\left(\mathrm{E}_{\mathrm{recon}}\right)$ of six model structures with different $\mathrm{Sr}^{2+}$ concentration were calculated using the total energy difference between simple perovskite and $\mathrm{n}=1 \mathrm{R}-\mathrm{P}$ perovskite by following equation:

$$
E_{\text {recon }}=\frac{1}{16} E_{R-P \text { perov }}+\frac{1}{2} E_{F e}+\frac{1}{2} E_{O_{2}}-\frac{1}{16} E_{\text {simpleperov }},
$$

Where $E_{R-P \text { perov }}$ and $E_{\text {simple perov }}$ are the total energy of simple perovskite $(2 \times 2 \times 4$ super cell $)$ and R-P perovskite $\left(2 \times 2 \times 1\right.$ super cell), $E_{F e}$ is total energy of body-centered cubic Fe metal unit cell, and $E_{\mathrm{O}_{2}}$ is the total energy of gas phase oxygen molecule.

The oxygen vacancy formation energies $\left(\mathrm{E}_{v f-\mathrm{O}}\right)$ of $\mathrm{Pr}_{0.5} \mathrm{Ba}_{0.5} \mathrm{TO}_{3-\delta}$, $\mathrm{Pr}_{05} \mathrm{Sr}_{0.5} \mathrm{TO}_{3-\delta}(\mathrm{T}=\mathrm{Mn}, \mathrm{Co}, \mathrm{Fe}$, and $\mathrm{Ni})$, and four model structures with different $\mathrm{Sr}^{2+}$ concentrations were calculated using the lattice oxygen on the $\mathrm{BO}_{2}$ layer since the phase reconstruction from simple perovskite $\left(\mathrm{ABO}_{3}\right)$ to $\mathrm{n}=1 \mathrm{R}-\mathrm{P}$ perovskite
$\left(\mathrm{A}_{2} \mathrm{BO}_{4}\right)$ requires the formation of both oxygen and $\mathrm{B}$-site vacancies. For the $\mathrm{Pr}_{0.5} \mathrm{Ba}_{0.5} \mathrm{TO}_{3-\delta}$ and $\mathrm{Pr}_{0.5} \mathrm{Sr}_{0.5} \mathrm{TO}_{3-\delta}(\mathrm{T}=\mathrm{Mn}, \mathrm{Co}, \mathrm{Fe}$, and $\mathrm{Ni})$ models, the most stable structure configurations were utilized for the oxygen vacancy formation energy calculations. For the four computational models with different $\mathrm{Sr}^{2+}$ concentrations, the most stable vacancy sites were utilized for $\mathrm{Ba}^{2+} / \mathrm{Sr}^{2+}$ mixed models with $\mathrm{Ba}: \mathrm{Sr}=6: 10$ and $\mathrm{Ba}: \mathrm{Sr}=4: 12$. The $\mathrm{E}_{v f-O}$ was calculated by following equation:

$$
E_{v f-O}=E_{\text {perov-defect }}+\frac{1}{2} E_{\mathrm{O}_{2}}-E_{\text {perov }}
$$

where $E_{\text {perov-defect }}$ and $E_{\text {perov }}$ are the total energies of PrO-terminated (001) perovskite slab model with and without the oxygen vacancy, respectively.

The co-segregation energy $\left(\mathrm{E}_{\text {co-seg }}\right)$ is defined as the total energy difference of two surface models that have different vacancy site. The co-segregation energies of four computational models with different $\mathrm{Sr}^{2+}$ concentrations were calculated by following equation:

$$
E_{c o-s e g}=E_{\left(F e-V_{O}\right) \text { surface }}-E_{\left(F e-V_{O}\right) \text { bulk }}
$$

where $E_{\left(\mathrm{Fe}-V_{O}\right)_{-} \text {surface }}$ and $E_{\left(\mathrm{Fe}-V_{\mathrm{O}}\right) \_ \text {bulk }}$ are total energies of $\mathrm{FeO}_{2}$-terminated (001) perovskite slab model that have oxygen vacancy on surface $\mathrm{FeO}_{2}$ and bulk $\mathrm{FeO}_{2}$ layer, respectively.

Furthermore, the Gibbs free energy for oxygen vacancy formation of eight samples were calculated to include the temperature and oxygen partial pressure factors in the $\mathrm{E}_{v f-O}$ calculations. The equations used for the $\mathrm{G}_{v f-O}$ calculations from the surface $\mathrm{AO}$ and $\mathrm{BO}_{2}$ layers in $\operatorname{Pr}_{0.5}(\mathrm{Ba} / \mathrm{Sr})_{0.5} \mathrm{TO}_{3-\delta}(\mathrm{T}=\mathrm{Mn}, \mathrm{Fe}, \mathrm{Co}$, and $\mathrm{Ni})$ are as follows:

$$
G_{v f-O}(\text { AOlayer })=E_{\text {perov-defect }}-E_{\text {perov }}+\frac{1}{2} \mu_{O_{2}}
$$




$$
\begin{gathered}
\mu_{\mathrm{O}_{2}}=E_{\mathrm{O}_{2}(g)}^{D F T}+E_{\mathrm{O}_{2}(g)}^{Z P E}+E_{\mathrm{O}_{2}(g)}^{\text {correction }}-T S_{\mathrm{O}_{2}(g)}+k_{B} T \ln \left(\frac{P_{\mathrm{O}_{2}}}{P_{0}}\right) \\
G_{v f-\mathrm{O}}\left(\mathrm{BO}_{2} \text { layer }\right)=E_{\text {perov-defect }}-E_{\text {perov }}+\left(\mu_{\mathrm{H}_{2} \mathrm{O}}-\mu_{\mathrm{H}_{2}}\right)+E_{a}^{O_{\text {vac }} \text { diffusion }} \\
\mu_{\mathrm{H}_{2} \mathrm{O}}=\left(\Delta H_{\mathrm{H}_{2} \mathrm{O}}^{\mathrm{exp}}+E_{\mathrm{H}_{2}(g)}^{D F T}+E_{\mathrm{H}_{2}(g)}^{Z P E}+\frac{1}{2}\left(E_{\mathrm{O}_{2}(g)}^{D F T}+E_{\mathrm{O}_{2}(g)}^{Z P E}+E_{\mathrm{O}_{2}(g)}^{\text {correction }}\right)\right) \\
-T S_{\mathrm{H}_{2} \mathrm{O}(g)}+k_{B} T \ln \left(\frac{P_{\mathrm{H}_{2} \mathrm{O}}}{P_{0}}\right) \\
\mu_{\mathrm{H}_{2}}=E_{\mathrm{H}_{2}(g)}^{D F T}+E_{\mathrm{H}_{2}(g)}^{Z P E}-T S_{\mathrm{H}_{2}(g)}+k_{B} T \ln \left(\frac{P_{\mathrm{H}_{2}}}{P_{0}}\right)
\end{gathered}
$$

The $E_{\text {perov-defect }}$ and $E_{\text {perov }}$ are the total energies of PrO-terminated (001) perovskite slab model with and without the oxygen vacancy, respectively. The $\mu_{\mathrm{O}_{2}}$, $\mu_{\mathrm{H}_{2}}$, and $\mu_{\mathrm{H}_{2} \mathrm{O}}$ are the Gibbs free energy of di-atomic oxygen molecule, hydrogen, and water molecule, respectively. The $E_{\mathrm{O}_{2}(g)}^{D F T}$ and $E_{H_{2}(g)}^{D F T}$ is the gas phase energy of ground state triplet $\mathrm{O}_{2}$ molecule and hydrogen molecule, respectively. The zero point energies of oxygen molecule $\left(E_{\mathrm{O}_{2}(g)}^{Z P E}\right)$ and hydrogen molecule $\left(E_{\mathrm{H}_{2}(g)}^{Z P E}\right)$ were extracted from the previous calculated value ${ }^{59}$. The standard entropy of gas phase oxygen $\left(S_{\mathrm{O}_{2}(g)}\right)$ was obtained from National Institute of Standards and Technology Chemistry Web-Book (http://webbook.nist.gov/chemistry). Moreover, the correction energy of oxygen molecule $\left(E_{\mathrm{O}_{2}(g)}^{\text {correction }}\right)$ was added to reconcile the $\mathrm{E}_{v f-O}$ differences between the results achieved via computational method (GGA functional) and real experimental results ${ }^{60}$. The temperature and $\mathrm{p}\left(\mathrm{O}_{2}\right)$ are $750^{\circ} \mathrm{C}$ and $10^{-9} \mathrm{~atm}$ for $\mathrm{G}_{v f-\mathrm{O}}$ calculations at the surface $\mathrm{AO}$ layer (Eq. 6 and 7) and the temperature, $\mathrm{p}\left(\mathrm{O}_{2}\right), \mathrm{p}\left(\mathrm{H}_{2}\right)$, and $\mathrm{p}\left(\mathrm{H}_{2} \mathrm{O}\right)$ values are $750^{\circ} \mathrm{C}, 10^{-9}, 0.1$, and $0.01 \mathrm{~atm}$, respectively, for $\mathrm{G}_{v f-O}$ calculations at the $\mathrm{BO}_{2}$ layer (Eq. 8, 9, and 10). Under this specified condition (reducing condition), we assumed that the reduction of $\mathrm{BO}_{2}$ layer occurred via two elementary steps: surface hydrogen oxidation reaction $\left(\mathrm{O}_{\text {lattice }}+\mathrm{H}_{2}(g) \leftrightarrow \mathrm{H}_{2} \mathrm{O}(g)\right)$ and oxygen vacancy diffusion toward the $\mathrm{BO}_{2}$ layer. The activation energy of oxygen vacancy diffusion $\left(E_{a}^{O_{\text {vac }} \text { diffusion }}: 0.95 \mathrm{eV}\right)$ was calculated from the electrochemical measurements (Arrhenius plot of area specific resistance) of $\operatorname{Pr}_{0.4} \mathrm{Sr}_{0.6} \mathrm{Fe}_{0.875} \mathrm{Mo}_{0.125} \mathrm{O}_{3-\delta}$ (PSFM) material under $\mathrm{H}_{2}$ condition ${ }^{61}$.

Electrochemical performance measurements. $\mathrm{La}_{0.9} \mathrm{Sr}_{0.1} \mathrm{Ga}_{0.8} \mathrm{Mg}_{0.2} \mathrm{O}_{3-\delta}$ (LSGM) powder was prepared by conventional solid-state reaction to fabricate LSGM electrolyte-supported symmetrical S-SOCs. Stoichiometric amounts of $\mathrm{La}_{2} \mathrm{O}_{3}$ (Sigma, 99.99\%), $\mathrm{SrCO}_{3}$ (Sigma, 99.99\%), $\mathrm{Ga}_{2} \mathrm{O}_{3}$ (Sigma, 99.99\%) and $\mathrm{MgO}$ (Sigma, 99.9\%) powders were first mixed in a mortar and then ball-milled in ethanol for $24 \mathrm{~h}$ to obtain the desired composition. After drying, the obtained powder was calcined at $1000^{\circ} \mathrm{C}$ for $6 \mathrm{~h}$. After formation of LSGM powder with desired stoichiometry, the electrolyte substrate was prepared by pressing at $2 \mathrm{MPa}$ for $30 \mathrm{~s}$ into cylindrical shape and then sintered at $1475^{\circ} \mathrm{C}$ for $5 \mathrm{~h}$. The thickness of LSGM electrolyte was polished to about $250 \mu \mathrm{m}$. $\mathrm{A} \mathrm{La}_{0.6} \mathrm{Ce}_{0.4} \mathrm{O}_{2-\delta}$ (LDC) as a buffer layer was also prepared by ball-milling stoichiometric amounts of $\mathrm{La}_{2} \mathrm{O}_{3}$ (Sigma, 99.99\%) and $\mathrm{CeO}_{2}$ (Sigma, 99.99\%) in ethanol for $24 \mathrm{~h}$ and then calcined at $1000{ }^{\circ} \mathrm{C}$ for $6 \mathrm{~h}$. Electrode slurries were prepared by mixing pre-calcined powders of PBSF with an organic binder (Heraeus V006) and acetone in 3:6:0.6 weight ratio. The electrode inks were applied onto the LSGM pellet by a screen-printing method and then sintered at $950^{\circ} \mathrm{C}$ for $4 \mathrm{~h}$ in air to achieve the desired porosity. The porous electrodes had an active area of $0.36 \mathrm{~cm}^{2}$ and a thickness of about $15 \mu \mathrm{m}$. The LDC layer was screen-printed between the electrode and electrolyte to prevent inter-diffusion of ionic species between electrode and electrolyte. The cells with configuration of Electrode |LDC |LSGM | LDC | Electrode were mounted on alumina tubes with ceramic adhesives (Ceramabond 552, Aremco) for electrochemical performance tests (Cross-sectional SEM image of the A-PBSF30 symmetrical cell given in Supplementary Fig. 20). Silver paste and silver wire were utilized for electrical connections to both the fuel electrode and air electrode. The entire cell was placed inside a furnace and heated to the desired temperature. I-V polarization curves of synthesized fuel cells with PBSF as both sides of electrodes were measured using a BioLogic Potentiostat in a temperature range of 700 to $800^{\circ} \mathrm{C}$ (temperature interval: $\left.50^{\circ} \mathrm{C}\right)$ in humidified hydrogen $\left(3 \% \mathrm{H}_{2} \mathrm{O}\right)$ at a flow rate of $100 \mathrm{ml} \mathrm{min}^{-1}$. Fuel cell evaluation under humidified $\mathrm{C}_{3} \mathrm{H}_{8}$ fuel $\left(3 \% \mathrm{H}_{2} \mathrm{O}\right)$ at a flow rate of $100 \mathrm{ml} \mathrm{min}{ }^{-1}$ were also performed for symmetrical solid oxide fuel cell (S-SOFC) test with cell composition A-PBSF30 | LDC | LSGM | LDC |A-PBSF30 from 700 to $800{ }^{\circ} \mathrm{C}$ (temperature interval: $50^{\circ} \mathrm{C}$ ) using a BioLogic Potentiostat. For the electrochemical performance test of S-SOC with the cell composition of A-PBSF30 | LDC | LSGM | LDC | A-PBSF30 during co-electrolysis, $50 \mathrm{ml} \mathrm{min}^{-1}$ of $\mathrm{H}_{2}$ and $\mathrm{CO}_{2}$ into a $\mathrm{H}_{2} \mathrm{O}$-containing bubbler (with a heating tape) were co-fed to fuel electrode and $100 \mathrm{ml} \mathrm{min}^{-1}$ of air was fed to air electrode. The in-operando quantitative analysis of the generated synthetic gas $\left(\mathrm{H}_{2}\right.$ and $\left.\mathrm{CO}\right)$ during co-electrolysis of $\mathrm{CO}_{2}$ and $\mathrm{H}_{2} \mathrm{O}$ (Ratio of $\mathrm{CO}_{2}: \mathrm{H}_{2}: \mathrm{H}_{2} \mathrm{O}=45: 45: 10$ ) for the A-PBSF30 symmetrical cell $\left(@ 800{ }^{\circ} \mathrm{C}\right.$ and $1.5 \mathrm{~V}$ ) was demonstrated by the gas chromatograph (Agilent $7820 \mathrm{~A}$ GC instrument) with a thermal conductivity detector and a packed column (Agilent carboxen 1000).

\section{Data availability}

The data measured, simulated, and analyzed in this study are available from the corresponding author on reasonable request.

Received: 10 March 2021; Accepted: 1 October 2021; Published online: 24 November 2021

\section{References}

1. Sengodan, S. et al. Layered oxygen-deficient double perovskite as an efficient and stable anode for direct hydrocarbon solid oxide fuel cells. Nat. Mater. 14, 205-209 (2015).

2. Neagu, D., Tsekouoras, G., Miller, D. N., Menard, H. \& Irvine, J. T. S. In situ growth of nanoparticles through control of non-stoichiometry. Nat. Chem. $\mathbf{5}$, 916-923 (2013).

3. Kang, K. N. et al. $\mathrm{Co}_{3} \mathrm{O}_{4}$ exsolved defective layered perovskite oxide for energy storage systems. ACS Energy Lett. 5, 3828-3836 (2020).

4. Joo, S. et al. Cation-swapped homogeneous nanoparticles in perovskite oxides for high power density. Nat. Commun. 10, 1-9 (2019).

5. Opitz, A. K. et al. Understanding electrochemical switchability of perovskitetype exsolution catalysts. Nat. Commun. 11, 1-10 (2020).

6. Irvine, J. T. S. et al. Evolution of the electrochemical interface in hightemperature fuel cells and electrolysers. Nat. Energy 1, 1-13 (2016).

7. Ding, D., Li, X., Lai, S. Y., Gerdes, K. \& Liu, M. Enhancing SOFC cathode performance by surface modification through infiltration. Energy Environ. Sci. 7, 552-575 (2014)

8. Schlupp, M. V. F., Evans, A., Martynczuk, J. \& Prestat, M. Micro-solid oxide fuel cell membranes prepared by aerosol-assisted chemical vapor deposition. Adv. Energy Mater. 4, 1-7 (2014).

9. Kwak, N. W. et al. In situ synthesis of supported metal nanocatalysts through heterogeneous doping. Nat. Commun. 9, 1-8 (2018).

10. Jun, A., Kim, J., Shin, J. \& Kim, G. Achieving high efficiency and eliminating degradation in solid oxide electrochemical cells using high oxygen-capacity perovskite. Angew. Chem. Int. Ed. 55, 12512-12515 (2016).

11. Choi, S. et al. A robust symmetrical electrode with layered perovskite structure for direct hydrocarbon solid oxide fuel cells: $\mathrm{PrBa}_{0.8} \mathrm{Ca}_{0.2} \mathrm{Mn}_{2} \mathrm{O}_{5+\delta}$. J. Mater. Chem. A. 4, 1747-1753 (2016).

12. Myung, J. H., Neagu, D., Miller, D. N. \& Irvine, J. T. S. Switching on electrocatalytic activity in solid oxide cells. Nature 537, 528-531 (2016).

13. Neagu, D. et al. In situ observation of nanoparticle exsolution from perovskite oxides: from atomic mechanistic insight to nanostructure tailoring. ACS Nano 13, 12996-13005 (2019).

14. Sun, Y. et al. New opportunity for in situ exsolution of metallic nanoparticles on perovskite parent. Nano Lett. 16, 5303-5309 (2016).

15. Kwon, O. et al. Self-assembled alloy nanoparticles in a layered double perovskite as a fuel oxidation catalyst for solid oxide fuel cells. J. Mater. Chem. A. 6, 15947-15953 (2018).

16. Joo, S. et al. Highly active dry methane reforming catalysts with boosted in situ grown $\mathrm{Ni}-\mathrm{Fe}$ nanoparticles on perovskite via atomic layer deposition. Sci. Adv. 6, 1-9 (2020).

17. Zhang, J., Gao, M. R. \& Luo, J. L. In situ exsolved metal nanoparticles: a smart approach for optimization of catalysts. Chem. Mater. 32, 5424-5441 (2020).

18. Kwon, O. et al. Exsolution trends and co-segregation aspects of self-grown catalyst nanoparticles in perovskites. Nat. Commun. 8, 1-7 (2017).

19. Liu, S., Liu, Q. \& Luo, J. L. Highly stable and efficient catalyst with in situ exsolved $\mathrm{Fe}-\mathrm{Ni}$ alloy nanospheres socketed on an oxygen deficient perovskite for direct $\mathrm{CO}_{2}$ electrolysis. ACS Catal. 6, 6219-6228 (2016).

20. Sun, Y. et al. A-site deficient perovskite: the parent for in situ exsolution of highly active, regenerable nano-particles as SOFC anodes. J. Mater. Chem. A. 3, 11048-11056 (2015).

21. Tsekouras, G., Neagu, D. \& Irvine, J. T. S. Step-change in high temperature steam electrolysis performance of perovskite oxide cathodes with exsolution of B-site dopants. Energy Environ. Sci. 6, 256-266 (2013).

22. Zhu, T., Troiani, H. E., Mogni, L. V., Han, M. \& Barnett, S. A. Ni-substituted $\mathrm{Sr}(\mathrm{Ti}, \mathrm{Fe}) \mathrm{O}_{3}$ SOFC anodes: achieving high performance via metal alloy nanoparticle exsolution. Joule 2, 478-496 (2018).

23. Gao, Y., Chen, D., Saccoccio, M., Lu, Z. \& Ciucci, F. From material design to mechanism study: nanoscale Ni exsolution on a highly active A-site deficient anode material for solid oxide fuel cells. Nano Energy 27, 499-508 (2016).

24. Kim, K. J. et al. Facet-dependent in situ growth of nanoparticles in epitaxial thin films: the role of interfacial energy. J. Am. Chem. Soc. 141, 7509-7517 (2019).

25. Neagu, D. et al. Demonstration of chemistry at a point through restructuring and catalytic activation at anchored nanoparticles. Nat. Commun. 8, 1-8 (2017).

26. Yang, C. et al. In situ fabrication of CoFe alloy nanoparticles structured $\left(\mathrm{Pr}_{0.4} \mathrm{Sr}_{0.6}\right)_{3}\left(\mathrm{Fe}_{0.85} \mathrm{Nb}_{0.15}\right)_{2} \mathrm{O}_{7}$ ceramic anode for direct hydrocarbon solid oxide fuel cells. Nano Energy 11, 704-710 (2015). 
27. Lv, H. et al. In situ investigation of reversible exsolution/dissolution of CoFe alloy nanoparticles in a Co-doped $\mathrm{Sr}_{2} \mathrm{Fe}_{1.5} \mathrm{Mo}_{0.5} \mathrm{O}_{6-\delta}$ cathode for $\mathrm{CO}_{2}$ electrolysis. Adv. Mater. 32, 1906193 (2020).

28. Yang, C. et al. Sulfur-tolerant redox-reversible anode material for direct hydrocarbon solid oxide fuel cells. Adv. Mater. 24, 1439-1443 (2012).

29. Du, Z. et al. High-performance anode material $\mathrm{Sr}_{2} \mathrm{FeMo}_{0.65} \mathrm{Ni}_{0.35} \mathrm{O}_{6-\delta}$ with in situ exsolved nanoparticle catalyst. ACS Nano. 10, 8660-8669 (2016).

30. Chung, Y. S. et al. In situ preparation of a $\mathrm{La}_{1.2} \mathrm{Sr}_{0.8} \mathrm{Mn}_{0.4} \mathrm{Fe}_{0.6} \mathrm{O}_{4}$ RuddlesdenPopper phase with exsolved Fe nanoparticles as an anode for SOFCs. J. Mater. Chem. A. 5, 6437-6446 (2017).

31. Park, S. et al. In situ exsolved Co nanoparticles on Ruddlesden-Popper material as highly active catalyst for $\mathrm{CO}_{2}$ electrolysis to CO. Appl. Catal. B Environ. 248, 147-156 (2019).

32. Kim, K. et al. Mechanistic insights into the phase transition and metal exsolution phenomena of $\operatorname{Pr}_{0.5} \mathrm{Ba}_{0.5} \mathrm{Mn}_{0.85} \mathrm{Co}_{0.15} \mathrm{O}_{3-\delta}$ from simple to layered perovskite under reducing conditions and enhanced catalytic activity. Energy Environ. Sci. 14, 873-882 (2021).

33. Vibhu, V. et al. Characterization of $\mathrm{PrNiO}_{3-\delta}$ as oxygen electrode for SOFCs. Solid State Sci. 81, 26-31 (2018).

34. Choi, S. et al. Highly efficient and robust cathode materials for low-temperature solid oxide fuel cells: $\mathrm{PrBa}_{0.5} \mathrm{Sr}_{0.5} \mathrm{Co}_{2-x} \mathrm{Fe}_{x} \mathrm{O}_{5+\delta}$. Sci. Rep. 3, 1-6 (2013).

35. Chen, C. \& Ciucci, F. Designing Fe-based oxygen catalysts by density functional theory calculations. Chem. Mater. 28, 7058-7065 (2016).

36. Brown, J. J., Ke, Z., Geng, W. \& Page, A. J. Oxygen vacancy defect migration in titanate perovskite surfaces: effect of the A-site cations. J. Phys. Chem. C. 122, 14590-14597 (2018)

37. Kwon, O. et al. Probing one-dimensional oxygen vacancy channels driven by cation-anion double ordering in perovskites. Nano Lett. 20, 8353-8359 (2020).

38. Neagu, D. et al. Nano-socketed nickel particles with enhanced coking resistance grown in situ by redox exsolution. Nat. Commun. 6, 1-8 (2015).

39. Niu, B. et al. In-situ growth of nanoparticles-decorated double perovskite electrode materials for symmetrical solid oxide cells. Appl. Catal. B Environ. 270, 118842 (2020).

40. Kim, H., Joo, S., Kwon, O., Choi, S. \& Kim, G. Cobalt-free $\operatorname{Pr}_{0.5} \mathrm{Ba}_{0.4} \mathrm{Sr}_{0.1} \mathrm{FeO}_{3-\delta}$ as a highly efficient cathode for commercial YSZ-supported solid oxide fuel cell. ChemElectroChem 7, 4378-4382 (2020).

41. Liu, B. Q., Dong, X., Xiao, G., Zhao, F. \& Chen, F. A novel electrode material for symmetrical SOFCs. Adv. Mater. 22, 5478-5482 (2010).

42. Lu, X. et al. Mo-doped $\operatorname{Pr}_{0.6} \mathrm{Sr}_{0.4} \mathrm{Fe}_{0.8} \mathrm{Ni}_{0.2} \mathrm{O}_{3-\delta}$ as potential electrodes for intermediate-temperature symmetrical solid oxide fuel cells. Electrochim. Acta 227, 33-40 (2017).

43. He, W., Wu, X., Dong, F. \& Ni, M. A novel layered perovskite electrode for symmetrical solid oxide fuel cells: $\mathrm{PrBa}\left(\mathrm{Fe}_{0.8} \mathrm{Sc}_{0.2}\right)_{2} \mathrm{O}_{5+\delta}$. J. Power Sources 363, 16-19 (2017).

44. Zhang, Y., Zhao, H., Du, Z., Świerczek, K. \& Li, Y. High-performance $\mathrm{SmBaMn}_{2} \mathrm{O}_{5+\delta}$ electrode for symmetrical solid oxide fuel cell. Chem. Mater. 31, 3784-3793 (2019).

45. Cai, H. et al. Cobalt-free $\mathrm{La}_{0.5} \mathrm{Sr}_{0.5} \mathrm{Fe}_{0.9} \mathrm{Mo}_{0.1} \mathrm{O}_{3-\delta}$ electrode for symmetrical SOFC running on $\mathrm{H}_{2}$ and CO fuels. Electrochim. Acta 320, 134642 (2019).

46. $\mathrm{Lu}, \mathrm{C}$. et al. Efficient and stable symmetrical electrode $\mathrm{La}_{0.6} \mathrm{Sr}_{0.4} \mathrm{Co}_{0.2} \mathrm{Fe}_{0.7} \mathrm{Mo}_{0.1} \mathrm{O}_{3-\delta}$ for direct hydrocarbon solid oxide fuel cells. Electrochim. Acta 323, 134857 (2019).

47. Hansen, J. B. Solid oxide electrolysis - a key enabling technology for sustainable energy scenarios. Faraday Discuss 182, 9-48 (2015).

48. Zhu, J. et al. Enhancing $\mathrm{CO}_{2}$ catalytic activation and direct electroreduction on in-situ exsolved $\mathrm{Fe} / \mathrm{MnO}_{x}$ nanoparticles from $(\mathrm{Pr}, \mathrm{Ba})_{2} \mathrm{Mn}_{2-y} \mathrm{Fe}_{y} \mathrm{O}_{5+\delta}$ layered perovskites for SOEC cathodes. Appl. Catal. B Environ. 268, 118389 (2020).

49. Zhou, Y. et al. Enhancing $\mathrm{CO}_{2}$ electrolysis performance with vanadium-doped perovskite cathode in solid oxide electrolysis cell. Nano Energy 50, 43-51 (2018).

50. Kim, C. et al. Highly efficient $\mathrm{CO}_{2}$ utilization via aqueous zinc-or aluminum- $\mathrm{CO}_{2}$ systems for hydrogen gas evolution and electricity production. Angew. Chem. Int. Ed. 58, 9506-9511 (2019).

51. Kresse, G. \& Hafner, J. Ab initio molecular dynamics for liquid metals. Phys. Rev. B 47, 558-561 (1993).

52. Sholl. D. \& Steckel, J. A. Density functional theory: a practical introduction. (John Wiley \& Sons, Inc., 2011)

53. Perdew, J. P., Burke, K. \& Ernzerhof, M. Generalized gradient approximation made simple. Phys. Rev. Lett. 77, 3865-3868 (1996).

54. Blöchl, P. E. Projector augmented-wave method. Phys. Rev. B. 50, 17953-17979 (1994).
55. Kresse, G. \& Joubert, D. From ultrasoft pseudopotentials to the projector augmented-wave method. Phys. Rev. B. 59, 1758-1775 (1999).

56. Kirklin, S. et al. The open quantum materials database (OQMD): assessing the accuracy of DFT formation energies. npj Comput. Mater. 1, 1-15 (2015).

57. Bouadjemi, B., Bentata, S., Abbad, A., Benstaali, W. \& Bouhafs, B. Halfmetallic ferromagnetism in $\mathrm{PrMnO}_{3}$ perovskite from first principles calculations. Solid State Commun. 168, 6-10 (2013).

58. Monkhorst, H. J. \& Pack, J. D. Special points for Brillouin-zone integrations. Phys. Rev. B. 13, 5188 (1976).

59. Nørskov, J. K. et al. Origin of the overpotential for oxygen reduction at a fuelcell cathode. J. Phys. Chem. B. 108, 17886-17892 (2004).

60. Wang, L., Maxisch, T. \& Ceder, G. Oxidation energies of transition metal oxides within the GGA + U framework. Phys. Rev. B. 73, 195107 (2006).

61. Zhang, D. et al. Preparation and characterization of a redox-stable $\mathrm{Pr}_{0.4} \mathrm{Sr}_{0.6} \mathrm{Fe}_{0.875} \mathrm{Mo}_{0.125} \mathrm{O}_{3-\delta}$ material as a novel symmetrical electrode for solid oxide cell application. Int. J. Hydrog. Energy 45, 21825-21835 (2020).

\section{Acknowledgements}

This work was supported by the Korea Institute of Energy Technology Evaluation and Planning (KETEP) and the Ministry of Trade, Industry \& Energy (MOTIE) of the Republic of Korea (No. 20213030030150) and the National Research Foundation (NRF) funded by the Ministry of Education (NRF-2019R1C1C1005801, NRF-

2021M3I3A1084292, and NRF-2021R1A2C3004019). This work was also supported by " $\mathrm{CO}_{2}$ utilization battery for hydrogen production based on fault-tolerance deep learning" (No. 1.200097.01). The Xray absorption fine structure experiments performed at the beamline $6 \mathrm{D}$ of Pohang Accelerator Laboratory was supported by the Pohang University of Science and Technology (POSTECH) and Ulsan National Institute of Science and Technology Central Research Facilities center (UCRF).

\section{Author contributions}

H.K. and O.K. carried out most of the experimental works and contributed to manuscript writing. C.L. performed DFT calculations. M.T.C. gave help on additional DFT calculations. J.O. performed the gas chromatography (GC) analysis. H.Y.J. conducted TEM measurements and analyzed the TEM images. S.C., J.W.H., and G.K. designed the experiments and analyzed the data. All authors contributed to the discussions and analysis of the results regarding the manuscript.

\section{Competing interests}

The authors declare no competing interests.

\section{Additional information}

Supplementary information The online version contains supplementary material available at https://doi.org/10.1038/s41467-021-26739-1.

Correspondence and requests for materials should be addressed to Sihyuk Choi, Jeong Woo Han or Guntae Kim.

Reprints and permission information is available at http://www.nature.com/reprints

Publisher's note Springer Nature remains neutral with regard to jurisdictional claims in published maps and institutional affiliations.

Open Access This article is licensed under a Creative Commons Attribution 4.0 International License, which permits use, sharing, adaptation, distribution and reproduction in any medium or format, as long as you give appropriate credit to the original author(s) and the source, provide a link to the Creative Commons license, and indicate if changes were made. The images or other third party material in this article are included in the article's Creative Commons license, unless indicated otherwise in a credit line to the material. If material is not included in the article's Creative Commons license and your intended use is not permitted by statutory regulation or exceeds the permitted use, you will need to obtain permission directly from the copyright holder. To view a copy of this license, visit http://creativecommons.org/ licenses/by/4.0/.

(C) The Author(s) 2021 